\title{
Quantifying the contribution of long-range transport to particulate matter (PM) mass loadings at a suburban site in the north-western Indo-Gangetic Plain (NW-IGP)
}

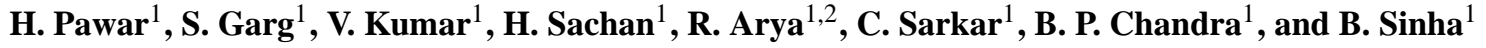 \\ ${ }^{1}$ Department of Earth and Environmental Sciences, Indian Institute of Science Education and Research Mohali, Sector 81, \\ S.A.S Nagar, Manauli PO, Punjab 140306, India \\ ${ }^{2}$ School of Chemical and Biomolecular Engineering, Cornell University, Ithaca, New York, USA
}

Correspondence to: B. Sinha (bsinha@iisermohali.ac.in)

Received: 22 January 2015 - Published in Atmos. Chem. Phys. Discuss.: 17 April 2015

Revised: 13 August 2015 - Accepted: 17 August 2015 - Published: 26 August 2015

\begin{abstract}
Many sites in the densely populated Indo-Gangetic Plain (IGP) frequently exceed the national ambient air quality standard (NAAQS) of $100 \mu \mathrm{g} \mathrm{m}^{-3}$ for $24 \mathrm{~h}$ average $\mathrm{PM}_{10}$ and $60 \mu \mathrm{g} \mathrm{m}^{-3}$ for $24 \mathrm{~h}$ average $\mathrm{PM}_{2.5}$ mass loadings, exposing residents to hazardous levels of particulate matter (PM) throughout the year.

We quantify the contribution of long-range transport to elevated PM levels and the number of exceedance events through a back-trajectory climatology analysis of air masses arriving at the IISER Mohali Atmospheric Chemistry facility $\left(30.667^{\circ} \mathrm{N}, 76.729^{\circ} \mathrm{E} ; 310 \mathrm{~m}\right.$ a.m.s.l.) for the period August 2011-June 2013. Air masses arriving at the receptor site were classified into six clusters, which represent synopticscale air-mass transport patterns.

Long-range transport from the west leads to significant enhancements in the average fine- and coarse-mode PM mass loadings during all seasons. The contribution of long-range transport from the west and south-west (source regions: Arabia, Thar Desert, Middle East and Afghanistan) to coarsemode PM varied between 9 and $57 \%$ of the total $\mathrm{PM}_{10-2.5}$ mass.

Local pollution episodes (wind speed $<1 \mathrm{~m} \mathrm{~s}^{-1}$ ) contributed to enhanced $\mathrm{PM}_{2.5}$ mass loadings during both the winter and summer seasons and to enhanced coarse-mode $\mathrm{PM}$ only during the winter season.

South-easterly air masses (source region: eastern IGP) were associated with significantly lower fine- and coarsemode PM mass loadings during all seasons.
\end{abstract}

The fraction of days in each season during which the PM mass loadings exceeded the national ambient air quality standard was controlled by long-range transport to a much lesser degree.

For the local cluster, which represents regional air masses (source region: NW-IGP), the fraction of days during which the national ambient air quality standard (NAAQS) of $60 \mu \mathrm{g} \mathrm{m}^{-3}$ for $24 \mathrm{~h}$ average $\mathrm{PM}_{2.5}$ was exceeded varied between $36 \%$ of the days associated with this synopticscale transport during the monsoon, and $95 \%$ during postmonsoon and winter seasons; the fraction of days during which the NAAQS of $100 \mu \mathrm{g} \mathrm{m}^{-3}$ for the $24 \mathrm{~h}$ average $\mathrm{PM}_{10}$ was exceeded, varied between $48 \%$ during the monsoon and $98 \%$ during the post-monsoon season.

Long-range transport was responsible for both, bringing air masses with a significantly lower fraction of exceedance days from the eastern IGP and air masses with a moderate increase in the fraction of exceedance days from the west (source regions: Arabia, Thar Desert, Middle East and Afghanistan).

In order to bring PM mass loadings into compliance with the NAAQS and to reduce the number of exceedance days, mitigation of regional combustion sources in the NW-IGP needs to be given highest priority. 


\section{Introduction}

India is a rapidly developing nation. Population growth, urbanisation and industrial development have led to increasing emissions, resulting in particulate matter (PM) mass loadings that frequently exceed the national ambient air quality standard (NAAQS) of $100 \mu \mathrm{g} \mathrm{m}^{-3}$ for $24 \mathrm{~h}$ average $\mathrm{PM}_{10}$ and $60 \mu \mathrm{g} \mathrm{m}^{-3}$ for $24 \mathrm{~h}$ average $\mathrm{PM}_{2.5}$ mass loadings. This exposes the residents to hazardous levels of PM throughout the year.

Daily particulate matter mass loadings show a clear correlation with daily mortality and morbidity from respiratory and cardio-vascular diseases (Englert, 2004; Kappos et al., 2004; Pope III and Dockery, 2006). The correlation between extreme PM mass loadings and mortality was recognised early in the history of air pollution research (Firket, 1931; Schrenk et al., 1949; Nemery et al., 2001) and the predicted disaster of the "London Fog" (Logan, 1953; Bell and Davis, 2001) resulted in first efforts to combat PM air pollution through legislation and regulatory intervention. However, the effect of moderate to low PM mass loadings on human health was recognised much later (Shy, 1979; Ware et al., 1981; Dockery et al., 1989, 1993; Schwartz, 1994; Pope III et al., 1995; Pope III, 2000) and the accumulated evidence has resulted in a revision of the air quality standards in many countries including India (NAAQS, 2009).

Many sites in the densely populated IGP are in violation of the NAAQS throughout the year except during the monsoon season, when removal through wet scavenging brings PM levels into compliance. Enhanced PM is associated with increased hospital visits/admission of patients with respiratory symptoms and increased mortality (Mohanraj and Azeez, 2004; Nag et al., 2005; Pandey et al., 2005; Kaushik et al., 2006). The complex interplay of natural windblown dust, trans-boundary air pollution and local sources imposes severe challenges on the Central Pollution Control Board, the local regulatory body in charge of enforcing the NAAQS. While it is clearly inappropriate to blame individual industrial units for natural windblown dust or trans-boundary air pollution, the contribution of these two factors to extreme events should not be used as an excuse to avoid all regulatory action. This study seeks to quantify the effect of long-range transport of both natural windblown dust and anthropogenic PM to the regional background PM mass loadings and to establish a baseline against which the enhancement due to local sources can be measured.

Back-trajectory models use archived meteorological data and allow for the identification of source regions of pollutants measured at a receptor site. Air-mass trajectories are defined as the path of an infinitesimally small air parcel. Back trajectories trace the air mass back in time and describe where the air mass reaching a receptor site originated.

Statistical analysis of large data sets has been a popular tool for identifying source regions of particulate matter. Such analysis attributes all changes in particulate mat- ter mass loading at a receptor site to spatially fixed sources and seeks to identify those sources by investigating the statistical correlation between air-mass origin and the particulate mass loadings observed at the receptor site. While wind rose or pollution rose plots are most appropriate for identifying local sources (Fleming et al., 2012), analysis of a large set of back trajectories (Stohl, 1996, 1998) has been a popular tool for identifying distant source regions of particulate matter (Borge et al., 2007; Abdalmogith and Harrison, 2005; Nyanganyura et al., 2008; Buchanan et al., 2002) and investigating trans-boundary particulate matter pollution (Miller et al., 2010; Grivas et al., 2008; Borge et al., 2007). Cluster analysis is a multivariate statistical technique that splits the data into a number of groups while maximising the homogeneity within each group and maximising the distance between groups.

The aim of the present study is to better understand the conditions under which PM mass loadings exceeding the national ambient air quality standard (NAAQS) of $100 \mu \mathrm{g} \mathrm{m}^{-3}$ for $24 \mathrm{~h}$ average $\mathrm{PM}_{10}$ and $60 \mu \mathrm{g} \mathrm{m}^{-3}$ for $24 \mathrm{~h}$ average $\mathrm{PM}_{2.5}$ (NAAQS, 2009) occur in the north-western Indo-Gangetic Plain (NW-IGP) and to quantify the contribution of longrange transport to those exceedance events. Here, we quantify the contribution of long-range transport to fine $\left(\mathrm{PM}_{2.5}\right)$ and coarse ( $\left.\mathrm{PM}_{10-2.5}\right)$ particulate matter (PM) using backtrajectory cluster analysis, pinpoint potential source regions of enhanced background PM mass loadings, and further attempt to constrain the origin of the particulate matter by correlating the observations with those of gas-phase combustion tracers $\left(\mathrm{CO}, \mathrm{NO}_{2}\right.$, benzene and acetonitrile). We analyse a 2-year data set (August 2011 till June 2013) measured at the Atmospheric Chemistry facility of the Indian Institute for Science Education and Research (IISER) Mohali.

\section{Materials and methods}

\subsection{Study location, air quality data and general meteorology}

We use 2 years (August 2011 till June 2013) of hourly data of fine $\left(\mathrm{PM}_{2.5}\right)$ and coarse $\left(\mathrm{PM}_{10-2.5}\right)$ particulate matter (PM) and gas-phase combustion tracers $\left(\mathrm{CO}, \mathrm{NO}_{2}\right.$, benzene and acetonitrile) measured at the Atmospheric Chemistry facility of the Indian Institute of Science Education and Research Mohali. The facility, the measurement techniques used, data coverage and data quality assurance protocols are described in great detail in Sinha et al. (2014); hence, only a brief description is provided here. Particulate matter $\left(\mathrm{PM}_{10}\right.$ and $\mathrm{PM}_{2.5}$ ) mass concentrations were measured using separate Thermo Fischer Scientific 5014i beta continuous ambient particulate monitors working on the principle of beta attenuation, $\mathrm{NO}_{2}$ measurements were performed by the chemiluminescence technique using a Thermo Fischer Scientific 42i trace-level analyser, carbon monoxide 

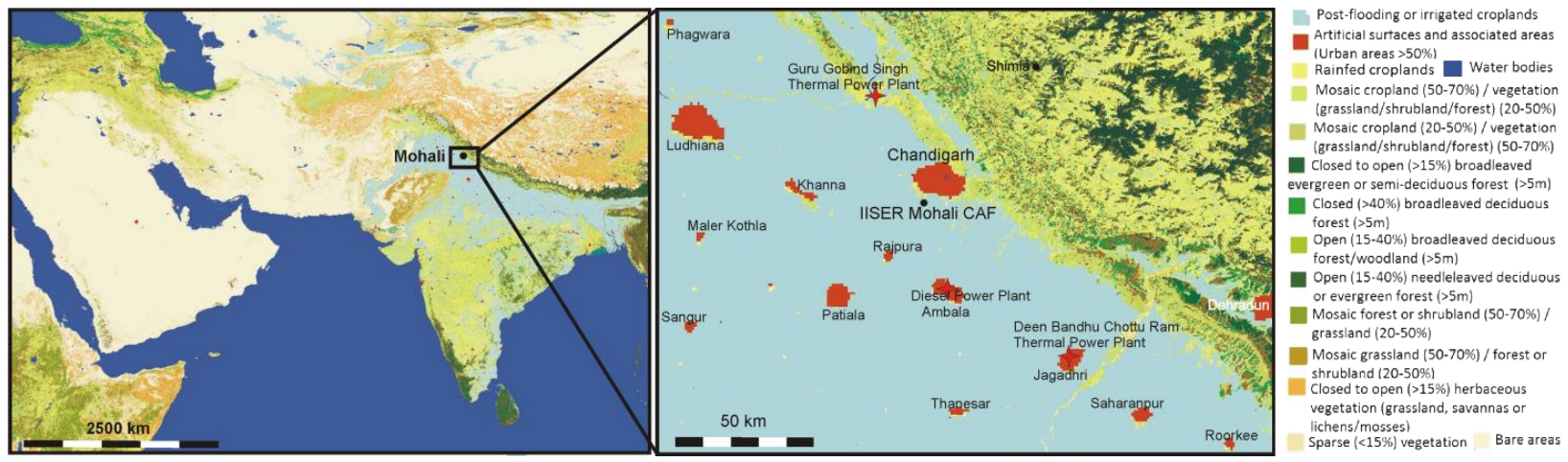

Figure 1. (Left) Location of Mohali on a land classification map (courtesy ESA GlobCover 2009 project). The site is located in the northwestern Indo-Gangetic Plain, close to the forested slopes of the foothills of the Himalayan mountain range. (Right) Exact location of the measurement facility and its spatial relationship with respect to the nearby cities, the mountain range and potential local point sources of particulate matter.

(CO) was measured by the gas filter correlation (GFC) nondispersive infrared (NDIR) technique using a Thermo Fischer Scientific 48i trace-level enhanced analyser, and the mixing ratios of benzene and acetonitrile were determined using a high-sensitivity proton transfer reaction quadrupole mass spectrometer (HS model 11-07HS-088; Ionicon Analytik Gesellschaft, Austria). The inlets of all instruments and the meteorological sensors are co-located and placed at a measurement height of $20 \mathrm{~m}$ a.g.l. (Sinha et al., 2014).

Figure 1 shows the location of the city of Mohali in the north-western Indo-Gangetic Plain in the Indian state of Punjab, close to the forested slopes of the foothills of the Himalayan mountain range on the left side. The measurement facility is located at a suburban site, south-west of the city centre of the "tri-city" - an urban agglomeration of the three cities of Chandigarh, Mohali and Panchkula - inside the residential campus of IISER Mohali $\left(30.667^{\circ} \mathrm{N}, 76.729^{\circ} \mathrm{E}\right.$; $310 \mathrm{~m}$ a.m.s.l.). On the right side, Fig. 1 shows a close-up illustrating the exact location of the measurement facility and its spatial relationship with respect to the nearby cities and potential local point sources of particulate matter and the mountain range.

Figure 2 shows wind rose plots for the winter (December-February), summer (March-June), monsoon (July-September) and post-monsoon (October and November) seasons. Most air masses impacting the site travel parallel to the mountain range and reach the facility from a north-westerly or south-easterly direction. Periods of calm (wind speed $<1 \mathrm{~m} \mathrm{~s}^{-1}$ ) account for only 4.5, 2.5, 5.2 and $8.7 \%$ of the total time during the winter, summer, monsoon, and post-monsoon seasons respectively, and slow transport (wind speed $1-5 \mathrm{~m} \mathrm{~s}^{-1}$ ) was observed 64.1, 48.7, 56.1 and $71.4 \%$ of the total time respectively. The high frequency with which rapid transport of air masses towards the facility (wind speed $\left.>5 \mathrm{~m} \mathrm{~s}^{-1}\right)$ was observed $(31.4,48.8,38.7$ and $19.9 \%$ of the total time during the winter, summer, monsoon, and post-monsoon seasons respectively) indicates that long-range

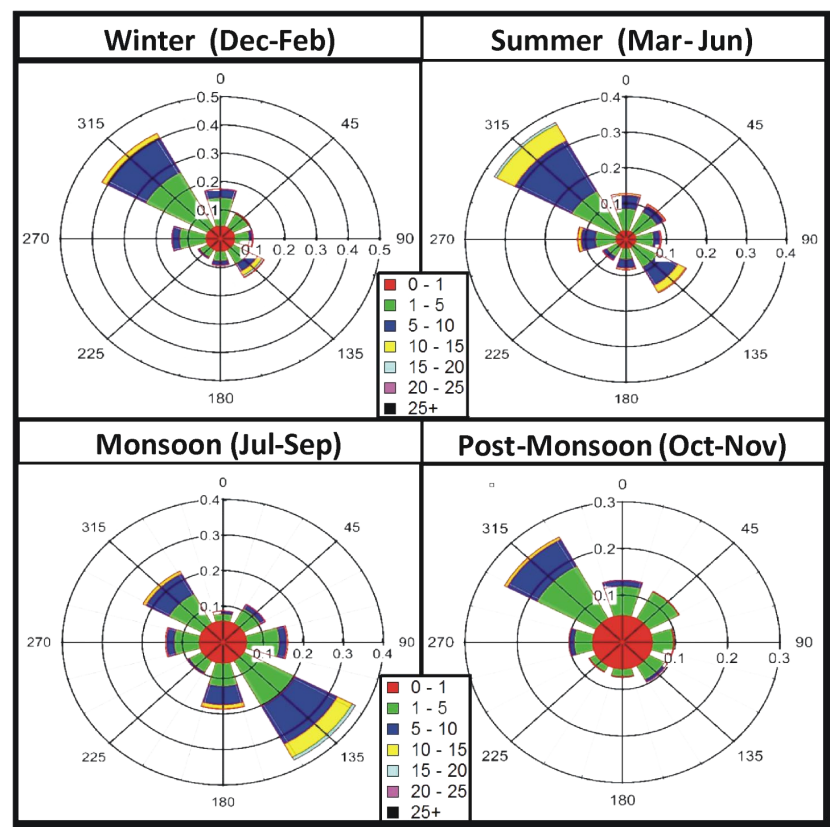

Figure 2. Wind rose plot for the measurement site for the winter (December-February), summer (March-June), monsoon (JulySeptember) and post-monsoon (October and November) seasons. Wind speed and wind direction were measured at a height of 20 m a.g.l.

transport potentially plays a significant role in determining pollutant loadings at the site. The general meteorology of the site is as follows.

During the winter season, weak northerlies or northwesterlies and a weak, low-level anti-cyclonic circulation prevails in the NW-IGP. The surface pressure map, the surface winds and $700 \mathrm{hPa}$ winds of NCEP Reanalysis derived data provided by the NOAA Physical Science Division, Boulder, Colorado, USA, are shown in Fig. S1a-c in the Supplement. Wintertime fog occurs frequently and fog formation 
is favoured by subsidence of air masses over the IGP, low temperatures, high relative humidity and low wind speeds $\left(<5 \mathrm{~m} \mathrm{~s}^{-1}\right)$. However, ground-level wind speeds at our site are generally not as low as the surface wind speeds of the NCAR Reanalysis data set would suggest. The seasonally averaged experimentally observed wind speed is $4.4 \mathrm{~m} \mathrm{~s}^{-1}$ and not $<2 \mathrm{~m} \mathrm{~s}^{-1}$. This underestimation of the surface wind speeds in the NW-IGP is not unique to this particular model and meteorological data set but also applies to e.g. Fig. 6 in Lawrence and Lelieveld (2010). Sporadic winter rains are generally associated with the western disturbance (Pisharoty and Desai, 1956; Agnihotri and Singh, 1982; Mooley, 1957; Dimri, 2004). The western disturbance is a terrain-locked low-pressure system that forms when an upper-level extratropical storm originating over the Mediterranean passes over the notch formed by the Himalayas and the Hindu Kush mountains. The resulting notch depression is small, $5^{\circ}$ latitude/longitude in size, and develops within an existing trough in the belt of subtropical westerly wind. South-westerly wind ahead of the trough brings moisture from the Arabian Sea, which encounters the Western Himalayas that lie almost normal to this moist wind. Part of the wind is channelled into the IGP which subsequently reaches the receptor site from the south-east. Fast westerly winds in winter are typically associated with a strong subtropical jet stream poised over westerly troughs.

During the summer season, the prevailing wind direction is north-westerly. Tropospheric subsidence over north-western India due to the "heat low" associated with westerly flow across Afghanistan and Pakistan channels air masses originating in the Middle East into the IGP (Fig. S1d-f in the Supplement). The boundary layer experiences a strong temperature inversion (Das, 1962) due to dust-induced cooling in the upper layers. The resulting steep horizontal pressure gradient is responsible for strong surface winds that carry dust and sand storms (Bryson and Swain, 1981). These loo winds are extremely hot and dry and are not adequately resolved by the NCEP Reanalysis meteorological data set (Fig. S1d-f in the Supplement), which shows a very moderate average surface wind speed of $1.5-2.5 \mathrm{~m} \mathrm{~s}^{-1}$ over the NW-IGP that stands in stark contrast to the observed seasonally average wind speed of $5.6 \mathrm{~m} \mathrm{~s}^{-1}$. During April, the centre of the subtropical jet stream is located over northern India and gives rise to cold subtropical westerlies in the upper troposphere. At the same time, the lower troposphere reaches very high temperatures due to quick response of the land to the overhead Sun. This favours severe thunderstorms with strong squalls at the leading edge of the downdraft during the summer season. Such thunderstorms can cause convective dust storms, locally known as Aandhi (Ramaswamy, 1956; Joseph, 1982). In March and April, south-easterly winds are generally associated with the western disturbance. The climatology of the western disturbance shows a significant inter-annual variability, as it is correlated with the polar/Eurasia teleconnection pattern. A weak circumpolar vortex can lead to an enhance- ment in the number of notch depressions and late "winter storms" in March and April (Lang and Barros, 2004). Southeasterly winds in June are generally associated with an earlier than usual onset of the monsoon. In normal years, the monsoon reaches Punjab in the first week of July.

During the monsoon season, the surface heat low located over the Pakistan region and the monsoon trough stretching from the NW-IGP to the Bay of Bengal dominate the general circulation over the IGP (Fig. S1g-i in the Supplement). The strength and position of the monsoon trough drive the "active-break" cycles of the rains on the intra-seasonal scale (Sikka and Gadgil, 1980; Goswami, 1998; Goswami et al., 2006a, b). During "active" spells the trough is located over southern or central India and cyclonic swirls form all across the trough. The prevailing wind direction during active spells is south-easterly. During "break" spells, the trough is located over the foothills of the Himalayas, the low-level jet originating off the coast of Somalia enters the IGP through the Indus Valley (Joseph and Raman, 1966). Cyclonic swirls are mostly absent and rains are suppressed everywhere except over the foothills (Joseph and Sijikumar, 2004). During break spells of the monsoon circulation, the prevailing wind direction is north-westerly. Break spells are associated with lower tropospheric inversions, dusty winds and lower troposphere anti-cyclonic vorticity over the IGP (Sikka, 2003; Rao and Sikka, 2005; Bhat, 2006). Both the observed wind direction and wind speeds of the surface winds during the monsoon season are poorly resolved by the meteorological data set. While the model suggests low wind speed $\left(<2 \mathrm{~m} \mathrm{~s}^{-1}\right)$ southwesterly winds dominate (Fig. S1g-i in the Supplement), actual observations show that north-westerly winds dominate during break spells, and south-easterly winds during active spells. The average wind speed is $5.1 \mathrm{~m} \mathrm{~s}^{-1}$. Most rainfall events occur during the "active spells" when the wind direction is south-easterly. However, occasional nighttime rainfall events are observed even during break spells in Punjab.

During the post-monsoon season, the prevailing wind direction is north-westerly. The retreating monsoon brings subsidence of dry central Asian air masses over the NW-IGP. In particular, during nighttime, katabatic winds reach the receptor site from the northern to eastern wind sectors. Winds are generally weak; the wind speed is less than $5 \mathrm{~m} \mathrm{~s}^{-1}$ for more than $80 \%$ of the time. The post-monsoon season shows the lowest discrepancy between modelled surface winds (1.5$\left.2 \mathrm{~m} \mathrm{~s}^{-1}\right)$ and the observed wind speed $\left(3.4 \mathrm{~m} \mathrm{~s}^{-1}\right)$ (Fig. S1j-1 in the Supplement). Surface wind vectors represent the observed nighttime flow at our site better, while the $700 \mathrm{haPa}$ wind vectors represent daytime observations better.

Since the purpose of this study is to investigate the contribution of long-range transport to PM pollution, we restricted our analysis to measurements obtained between 12:00 and 16:00 LT (UTC + 05:30) during the day and between 03:00 and 06:00 LT (UTC + 05:30) at night as depicted in Fig. 3, and consider calm conditions with wind speeds of less than $1 \mathrm{~m} \mathrm{~s}^{-1}$ separately. 
The daytime period was selected, because the local daytime boundary layer reaches its maximum height around 14:00 and the contribution of long-range transport to PM is highest in the time period centred on this time.

The nighttime period was selected because the contribution of local sources, in particular the contribution of local traffic, construction activity and biomass combustion to air pollution, is least during late night and early morning hours.

Figure 3 shows that both fine-mode PM $\left(\mathrm{PM}_{2.5}\right.$, bottom panels) and coarse-mode PM ( $\mathrm{PM}_{10-2.5}$, top panels) show a bimodal distribution with a peak in the morning and the evening due to local traffic and biomass combustion emissions and a low in the mid-day hours and the early morning hours during all seasons (Fig. 3). The bimodal behaviour is most pronounced during the post-monsoon season, when low wind speeds prevail and local and regional sources dominate the aerosol mass loading. The bimodal behaviour is weakest during the monsoon season, when active convection and high wind speeds reduce the influence of local sources. Finemode PM shows the lowest mass loadings during mid-day, when the boundary layer is highest, while coarse-mode PM shows the lowest mass loadings in the early morning hours.

During the summer and monsoon seasons, there is a pronounced difference between mean and median coarse-mode PM loadings. This discrepancy is caused by the contribution of episodic events (dust storms) to coarse-mode PM in both seasons. For our back-trajectory analysis, we calculated the median PM mass loading (see the Supplement) and gasphase mixing ratio of $\mathrm{CO}$, benzene and acetonitrile for the period in question. For rainfall we provided the sum (total precipitation in the time window in question) rather than the median, as we consider the total rainfall a better indicator of wet scavenging.

\subsection{Back-trajectory modelling}

We computed 3-day ( $72 \mathrm{~h}$ ) backward trajectories using the HYSPLIT_ 4 (HYbrid Single Particle Lagrangian Integrated Trajectory) model in ensemble mode using the National Oceanic and Atmospheric Administration's Global Data Acquisition System (GDAS) meteorology (Draxler and Rolph, 2013; Draxler and Hess, 1998) as input. We calculated ensemble runs for air masses arriving at the site $\left(30.667^{\circ} \mathrm{N}\right.$, $76.729^{\circ} \mathrm{E}$ ) at $20 \mathrm{~m}$ above the ground (the approximate sampling height for all instruments). The model was run twice daily with an arrival time of 09:00 UTC (14:30 local daytime) and 23:00 UTC (04:30 local nighttime). Due to the close proximity of the site to the Himalayan mountain range, the trajectory output was found to be very sensitive to the model's input data. The IISER Mohali air quality station $\left(30.667^{\circ} \mathrm{N}, 76.729^{\circ} \mathrm{E}\right)$ is located in the Indo-Gangetic Plain (IGP) at an altitude of $310 \mathrm{~m}$ a.m.s.l. approximately $20 \mathrm{~km}$ south-west of the Shivalik hills, but the model's terrain height at the receptor site is $667.6 \mathrm{~m}$ a.m.s.l. for the GDAS meteorological data field and $1249.9 \mathrm{~m}$ a.m.s.l. for the reanalysis meteorological data field for a single trajectory arriving at the site. We calculated trajectory ensembles for our site using both data sets. The trajectory ensemble option starts multiple trajectories from the selected starting location. Each member of the trajectory ensemble is calculated by offsetting the meteorological data by a fixed grid factor (1 meteorological grid point in the horizontal and 0.01 sigma units in the vertical), which results in 27 trajectories. The model's terrain height varied between 200 and $3500 \mathrm{~m}$ a.m.s.l. for individual runs of the trajectory ensemble for the GDAS meteorological data field and between 240 and $5100 \mathrm{~m}$ a.m.s.l. for the reanalysis meteorological data field. We conclude that the GDAS meteorological data field performs better in modelling the terrain at our site, and all further analysis in this work uses this meteorological data field.

Out of the 27 trajectories in the ensemble run, only 3 trajectories are consistent with the measurement site, Mohali, being located in the plain ( $<400$ ma.m.s.l.) and Shimla, a mountain site $60 \mathrm{~km}$ north-east of our site (Fig. 1) at $31.103^{\circ} \mathrm{N}, 77.172^{\circ} \mathrm{E}$, being located in the mountains ( $>400 \mathrm{~m}$ a.m.s.l.). To ensure that this sensitivity of the model does not affect the results of our study, we selected these three trajectories for further analysis.

Borge et al. (2007) have recently emphasised the importance of specifying adequate arrival heights for the outcome due to possible large variation in the wind speed and direction with height above the ground. Kassomenos et al. (2010), too, found a dependency of clustering outcome on the arrival heights of the trajectories. At our site, we find that the Himalayan mountain range acts as a great barrier and air masses are funnelled into the IGP. Consequently there is little dependency of the trajectory run outcome on arrival heights $\leq 500$ ma.g.l., as long as the meteorological input data set represents the Himalayan mountain range topography adequately. The local wind direction observed at the site generally agrees with the wind vector at $10 \mathrm{ma.g} .1$. used in the GDAS meteorological data field.

\subsection{Back-trajectory cluster analysis}

Cluster analysis is a statistical method used to group data in large data sets into a small number of groups of similar data known as clusters. In this work we have used air masses' trajectory coordinates (time steps) as the clustering variables. A non-hierarchical method known as the $k$ means procedure has been used in this study. The air mass back trajectories were subjected to $k$ means clustering using a freeware called PAST (PAleontological STatistics). The number of clusters " $k$ " is to be specified by the user prior to clustering. The assignment of back trajectories to clusters is initially random. In an iterative procedure, trajectories are then moved to the cluster which has the closest cluster mean in Euclidean distance, and the cluster means are updated accordingly (Bow, 1984). This process continues until the process of hopping from one cluster to another ceases. As a normal artefact of 


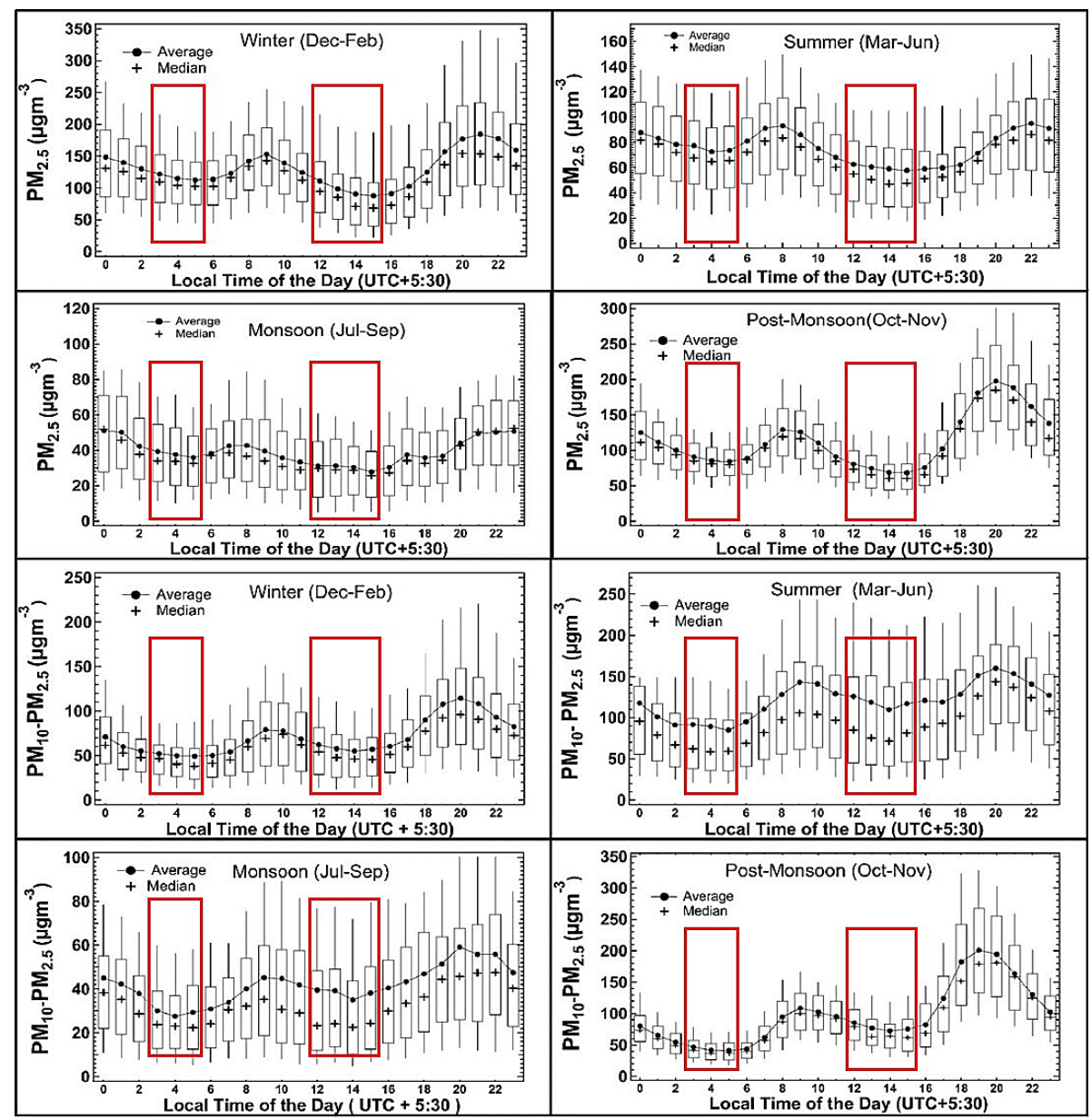

Figure 3. Diel box and whisker plots for fine-mode (top four panels) and coarse-mode (bottom four panels) particulate matter for the winter, summer, monsoon and post-monsoon seasons for the period November 2011 to August 2013 respectively. The box indicates the upper and lower quarter values; the cross indicates the median and the dots connected by lines provide the mean. The whiskers indicate the 5th and 95 th percentiles respectively. Periods of calm $\left(<1 \mathrm{~ms}^{-1}\right)$ have been excluded while preparing the graph. The interval highlighted in red shows the daytime low (12:00 to 16:00 LT) and nighttime low (03:00 to 06:00 LT).

the $k$ means clustering algorithm, the result is dependent upon the seed used for clustering (Kassomenos et al., 2010). Therefore, to get a robust result, clustering was initialised with 11 different trajectory orders and we selected the clustering result with the lowest root mean square difference for each predefined number of clusters.

The root mean square difference for an individual latitude and longitude value is given by

$\operatorname{RMSD}=\sqrt{\left(x_{i}-\bar{x}\right)^{2}}+\sqrt{\left(y_{i}-\bar{y}\right)^{2}}$

where $x_{i}$ and $y_{i}$ stand for the latitude and longitude of the individual trajectory for a given hour and $\bar{x}$ and $\bar{y}$ for the cluster mean latitude and longitude of the same hour for the cluster to which that trajectory belongs. The total root mean square difference t-RMSD is the sum over all the RMSD values for a given set of back trajectories.
We selected the optimal number of clusters that best describe the different air-flow patterns to our site by computing the change in the minimum t-RMSD while increasing the number of clusters from $n$ to $n+1$. This change in the minimum t-RMSD decreases abruptly as clusters of trajectories which are significantly different in terms of wind directions and speeds are separated from each other (Dorling et al., 1992). A threshold of $5 \%$ change has been adopted (Brankov et al., 1998; Dorling et al., 1992) as an indication of the number of clusters to be retained.

\section{Results and discussions}

\subsection{Optimisation of the number of clusters}

The number of clusters was optimised by minimising the t-RMSD change for an increase in the number of clusters, 


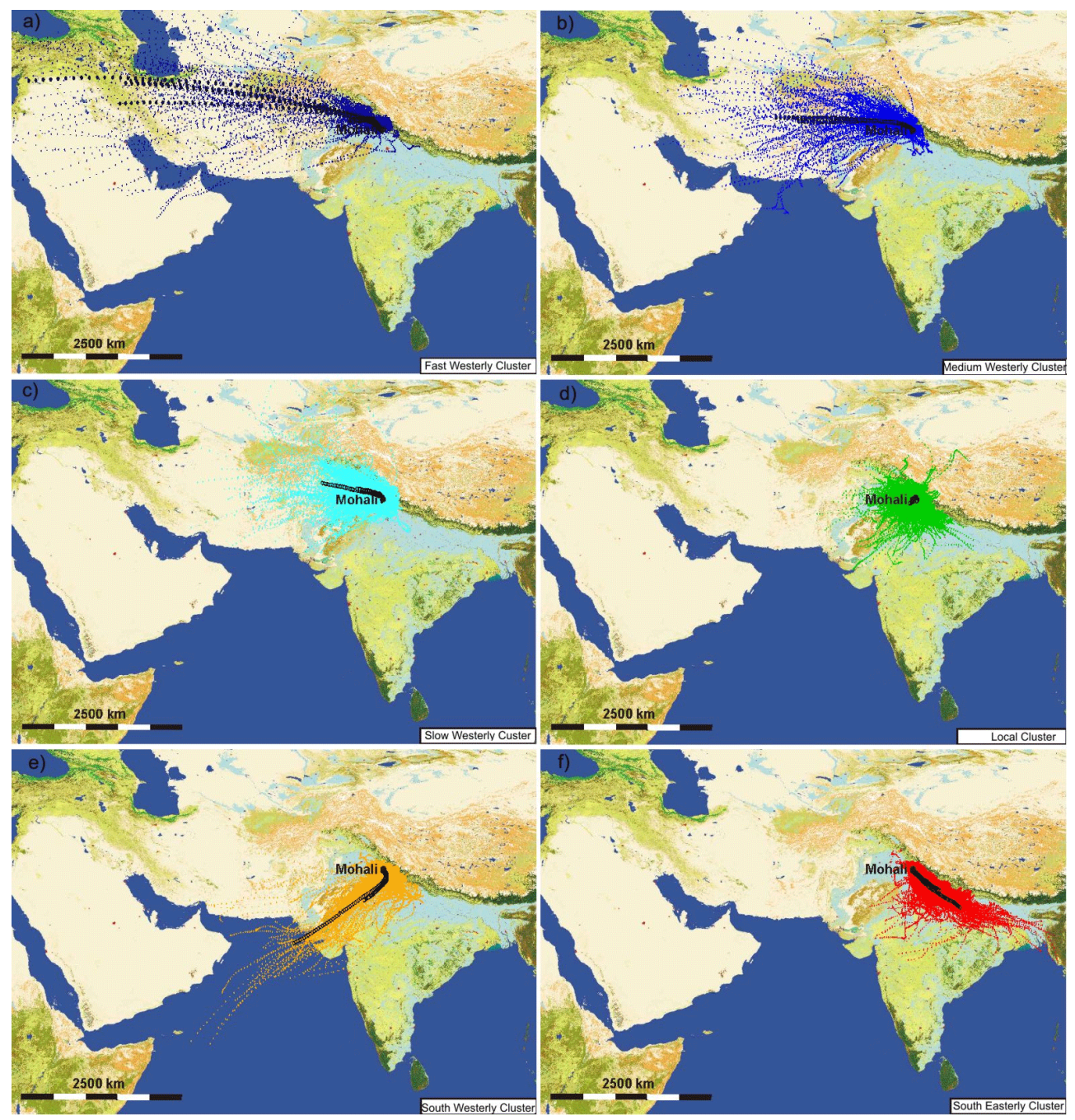

Figure 4. (a-f) All individual trajectories that contributed to each of the clusters and the cluster mean, superimposed on a land classification map (courtesy of the ESA GlobCover 2009 project). The length of each mean trajectory is 3 days and the distance between two successive data points represents a $1 \mathrm{~h}$ interval. The average trajectory of each cluster has been superimposed using circles with a black outline.

while retaining as few clusters as possible. Figure $\mathrm{S} 2$ in the Supplement shows the percent change in t-RMSD for a subsequent increase in the number of clusters. The largest \% decrease in t-RMSD is observed when the number of clusters is increased to 2 and subsequently 3 . This corresponds to two major airflow corridors (south-easterly flow and westerly flow) and a local cluster. Increasing the number of clusters beyond this number allows splitting of the air masses in the western and south-eastern corridors into several groups according to their transport speed and introduces a southwesterly cluster. Initially, we identified the optimum number of clusters as seven; however, two of these seven clusters (fast north-westerly flow A and B) were classified into two different groups only, because for fast north-westerly flow A, all three trajectories of the ensemble run showed equal transport speed, while for fast north-westerly flow B, two of the three trajectory solutions in the ensemble indicated slow air- mass transport (trajectories arriving at 20 ma.g.l., Fig. S3 in the Supplement), while one solution supported rapid transport (trajectory arriving at $250 \mathrm{ma.g.l.}$, Fig. S3 in the Supplement). Locally measured meteorological parameters indicated that both clusters are associated with hot dry Loo winds and dust storms during summer and above-average wind speeds during other seasons. Therefore, both clusters were combined into one fast westerly cluster, and the final number of optimum clusters was six.

\subsection{Spatial and dynamic patterns of the air flow associated with the clusters}

Figure $4 \mathrm{a}-\mathrm{f}$ shows the trajectories of the cluster averages and individual trajectories associated with each cluster identified by $k$ means clustering superimposed on a land classification map (courtesy of the ESA GlobCover 2009 project). The 
Table 1. Average of the locally measured meteorological parameters for daytime/nighttime for the different clusters and seasons. For solar radiation we provided the daytime average only. For rain we calculated the sum of the rainfall instead of the average and the numbers in brackets represent the number of rain events.

\begin{tabular}{|c|c|c|c|c|c|c|c|}
\hline & $\begin{array}{l}\text { Fast } \\
\text { westerly }\end{array}$ & $\begin{array}{l}\text { Medium } \\
\text { westerly }\end{array}$ & $\begin{array}{l}\text { Slow } \\
\text { westerly }\end{array}$ & Local & $\begin{array}{l}\text { South- } \\
\text { westerly }\end{array}$ & $\begin{array}{l}\text { South- } \\
\text { easterly }\end{array}$ & Calm \\
\hline & \multicolumn{7}{|c|}{ WINTER (Dec-Feb) } \\
\hline$T\left({ }^{\circ} \mathrm{C}\right)$ & $18.9 / 8.5$ & $17.7 / 9.4$ & $17.5 / 9.3$ & $17.7 / 9.8$ & $15.6 / 12.7$ & $18.3 / 12.0$ & $16.6 / 10.4$ \\
\hline $\mathrm{RH}(\%)$ & $43.6 / 82.5$ & $49.5 / 79.6$ & $50.0 / 79.5$ & $53.7 / 79.9$ & $57.8 / 74.5$ & $57.2 / 77.8$ & $62.2 / 79.7$ \\
\hline Wind speed $\left(\mathrm{m} \mathrm{s}^{-1}\right)$ & $7.0 / 5.0$ & $8.2 / 3.2$ & $5.7 / 3.0$ & $5.4 / 3.5$ & $5.4 / 6.0$ & $6.9 / 4.8$ & $0.8 / 0.7$ \\
\hline Wind direction & $302 / 319$ & $270 / 303$ & $306 / 294$ & $292 / 304$ & $298 / 240$ & $241 / 188$ & $235 / 139$ \\
\hline Absolute humidity $\left(\mathrm{g} \mathrm{m}^{-3}\right)$ & $7.4 / 7.2$ & $7.9 / 7.3$ & $7.8 / 7.3$ & $8.5 / 7.6$ & $8.1 / 8.6$ & $9.4 / 8.5$ & $9.2 / 7.9$ \\
\hline Solar radiation $\left(\mathrm{W} \mathrm{m}^{-2}\right)$ & 414 & 331 & 381 & 376 & 362 & 338 & 307 \\
\hline \multirow[t]{2}{*}{ Rain (mm) } & - & - & - & $7.7(2)$ & - & $50.7(11)$ & $27.3(8)$ \\
\hline & \multicolumn{7}{|c|}{ SUMMER (Mar-Jun) } \\
\hline$T\left({ }^{\circ} \mathrm{C}\right)$ & $31.7 / 19.3$ & $32.6 / 20.3$ & $35.9 / 26.5$ & $32.1 / 22.7$ & $32.5 / 25.2$ & $29.5 / 22.9$ & $34.2 / 23.3$ \\
\hline $\mathrm{RH}(\%)$ & $23.4 / 58.8$ & $22.1 / 50.7$ & $24.3 / 44.7$ & $28.7 / 51.8$ & $36.2 / 52.5$ & $44.1 / 64.1$ & $29.0 / 53.3$ \\
\hline Wind speed $\left(\mathrm{m} \mathrm{s}^{-1}\right)$ & $9.1 / 5.6$ & $7.6 / 3.6$ & $7.7 / 4.5$ & $7.2 / 4.3$ & $7.9 / 4.5$ & $7.0 / 5.6$ & $0.9 / 0.7$ \\
\hline Wind direction & $312 / 308$ & $306 / 124$ & $288 / 280$ & $298 / 264$ & $182 / 135$ & $171 / 152$ & $209 / 186$ \\
\hline Absolute humidity $\left(\mathrm{g} \mathrm{m}^{-3}\right)$ & $8.1 / 10.3$ & $8.0 / 9.4$ & $10.3 / 11.7$ & $10.0 / 11.0$ & $12.9 / 12.8$ & $13.5 / 13.8$ & $11.3 / 11.7$ \\
\hline Solar radiation $\left(\mathrm{W} \mathrm{m}^{-2}\right)$ & 633 & 607 & 593 & 586 & 519 & 569 & 548 \\
\hline \multirow[t]{2}{*}{ Rain $(\mathrm{mm})$} & - & - & $8.5(3)$ & $28.5(5)$ & $18.6(2)$ & $35.8(10)$ & $27(27)$ \\
\hline & \multicolumn{7}{|c|}{ MONSOON (Jul-Sep) } \\
\hline$T\left({ }^{\circ} \mathrm{C}\right)$ & - & - & $32.9 / 25.6$ & $32.4 / 26.3$ & $30.6 / 26.0$ & $31.3 / 27.1$ & $32.3 / 26.5$ \\
\hline $\mathrm{RH}(\%)$ & - & - & $50.5 / 80.1$ & $57.5 / 82.0$ & $68.0 / 85.2$ & $64.9 / 81.8$ & $61.7 / 83.6$ \\
\hline Wind speed $\left(\mathrm{m} \mathrm{s}^{-1}\right)$ & - & - & $8.5 / 4.5$ & $6.4 / 3.2$ & $5.4 / 4.1$ & $6.3 / 4.2$ & $0.8 / 0.7$ \\
\hline Wind direction & - & - & $309 / 191$ & $280 / 148$ & $182 / 124$ & $166 / 128$ & $206 / 132$ \\
\hline Absolute humidity $\left(\mathrm{g} \mathrm{m}^{-3}\right)$ & - & - & $18.4 / 19.9$ & $20.4 / 21.2$ & $22.0 / 21.7$ & $21.7 / 22.1$ & $21.8 / 21.8$ \\
\hline Solar radiation $\left(\mathrm{W} \mathrm{m}^{-2}\right)$ & - & - & 565 & 515 & 430 & 472 & 499 \\
\hline \multirow[t]{2}{*}{ Rain $(\mathrm{mm})$} & - & - & $0.4(1)$ & $33.8(4)$ & $74.1(3)$ & $142.2(9)$ & $36(29)$ \\
\hline & \multicolumn{7}{|c|}{ POST-MONSOON (Oct-Nov) } \\
\hline$T\left({ }^{\circ} \mathrm{C}\right)$ & $23.3 / 12.8$ & $23.6 / 12.9$ & $28.0 / 18.2$ & $27.3 / 17.3$ & - & - & $28.1 / 17.4$ \\
\hline RH $(\%)$ & $35.7 / 72.9$ & $22.3 / 74.2$ & $34.1 / 64.2$ & $34.9 / 67.7$ & - & - & $34.6 / 68.0$ \\
\hline Wind speed $\left(\mathrm{m} \mathrm{s}^{-1}\right)$ & $6.3 / 2.9$ & $9.2 / 3.9$ & $5.5 / 2.7$ & $5.3 / 2.6$ & - & - & $0.7 / 0.7$ \\
\hline Wind direction & $310 / 175$ & $313 / 315$ & $310 / 71$ & $304 / 174$ & - & - & $214 / 115$ \\
\hline Absolute humidity $\left(\mathrm{g} \mathrm{m}^{-3}\right)$ & $7.7 / 8.5$ & $8.0 / 8.7$ & $9.7 / 10.5$ & $9.5 / 10.4$ & - & - & $9.8 / 10.6$ \\
\hline Solar radiation $\left(\mathrm{W} \mathrm{m}^{-2}\right)$ & 409 & 417 & 447 & 422 & - & - & 461 \\
\hline Rain (mm) & - & - & - & $3.1(2)$ & - & - & $0.8(2)$ \\
\hline
\end{tabular}

length of each mean trajectory is 3 days and the distance between two successive data points represents the $1 \mathrm{~h}$ interval. We find six distinct flow patterns, south-easterly flow $(N=$ 263), south-westerly flow $(N=79)$, fast $(N=78)$, medium $(N=83)$ and slow $(N=305)$ westerly flow, and a local cluster $(N=556)$. Although considerable variability is observed between the individual trajectories contributing to each of the clusters, in particular for the "local" cluster (Fig. 4d), each cluster of trajectories represents a distinct air-mass fetch region. Figure S3 in the Supplement depicts the mean height (ma.g.1.) of the mean trajectories during the 3 days before their arrival at the receptor site. Trajectories from the slow, medium and fast westerly clusters descend from the free troposphere to reach the receptor site. Fast and medium west- erly air masses show a rapid descent in the last $30 \mathrm{~h}$ prior to reaching the receptor site and are generally associated with high wind speeds, while slow westerly air masses display a gradual subsidence. The south-easterly, south-westerly and local clusters remain within the convective boundary layer throughout.

Figure 5 shows the temporal distribution of the air flows for the six clusters determined with respect to the different seasons and Table 1 presents the locally measured meteorological parameters for daytime/nighttime for each cluster and season. A detailed description of the meteorological conditions and synoptic-scale air-mass flow associated with each of the clusters can be found in the Supplement. 
Table 2. Lower limit for the contribution of long-range transport and local pollution events to PM mass loadings in $\% \pm 1 \sigma$ of the total PM. "Negative" indicates that the PM mass loadings are not enhanced compared to the local cluster, which represent the regional background levels.

\begin{tabular}{|c|c|c|c|c|c|c|}
\hline & $\begin{array}{l}\text { Fast } \\
\text { westerly }\end{array}$ & $\begin{array}{l}\text { Medium } \\
\text { westerly }\end{array}$ & $\begin{array}{l}\text { Slow } \\
\text { westerly }\end{array}$ & $\begin{array}{l}\text { South- } \\
\text { westerly }\end{array}$ & $\begin{array}{l}\text { South- } \\
\text { easterly }\end{array}$ & Calm \\
\hline & & & $\mathrm{PM}_{2.5}$ & & & \\
\hline Winter & Negative & $7 \pm 4$ & $13 \pm 9$ & Negative & Negative & $22 \pm 15$ \\
\hline Summer & $20 \pm 15$ & $4 \pm 3$ & $31 \pm 21$ & $10 \pm 8$ & Negative & $13 \pm 8$ \\
\hline Monsoon & Negative & Negative & $15 \pm 11$ & Negative & Negative & Negative \\
\hline Post-monsoon & $18 \pm 10$ & $11 \pm 7$ & Negative & Negative & Negative & Negative \\
\hline Winter & $18 \pm 8$ & $28 \pm 16$ & $\begin{array}{l}\mathrm{PM}_{10-2.5} \\
22 \pm 15\end{array}$ & $9 \pm 5$ & Negative & $14 \pm 10$ \\
\hline Summer & $57 \pm 49$ & $27 \pm 21$ & $34 \pm 28$ & $34 \pm 26$ & Negative & Negative \\
\hline Monsoon & Negative & Negative & $29 \pm 11$ & Negative & Negative & Negative \\
\hline Post-monsoon & $27 \pm 18$ & $31 \pm 21$ & $9 \pm 6$ & Negative & Negative & Negative \\
\hline
\end{tabular}

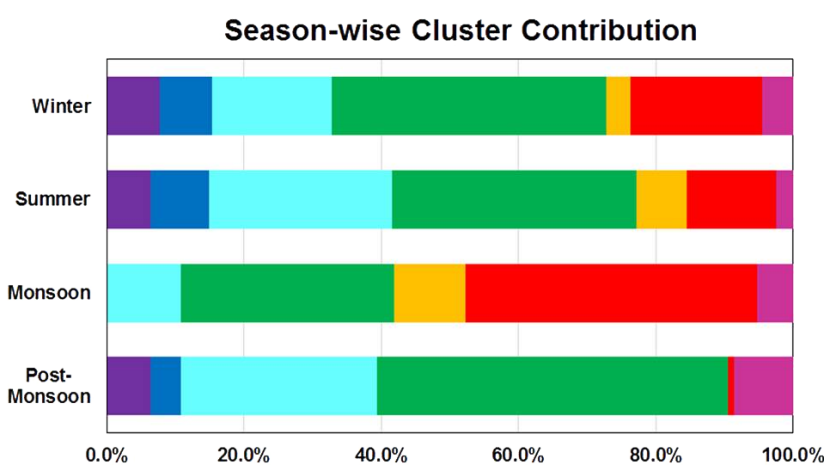

Figure 5. Contribution of individual clusters to air-mass flow for all four seasons. Magenta: calm; red: south-easterly cluster; orange: south-westerly cluster; green: local cluster; light blue: slow westerly cluster; dark blue: medium westerly cluster; purple: fast westerly cluster.

\subsection{Impact of air-mass transport on particulate matter (PM) mass loadings}

To quantify the contribution of long-range transport to particulate matter mass loadings at the receptor site, we calculated the cluster average mass loadings of coarse- and fine-mode particulate matter at the receptor site (Fig. 6) and the enhancement of PM mass loadings above the levels observed for the "local" cluster which represents the regional background pollution in the NW-IGP best (Table 2). The enhancement is expressed in \% of the total PM mass loading observed for the respective cluster. We determined whether the differences in PM mass loadings between the different clusters are significant using Levene's test for homogeneity of variance based on means and used the pairwise comparison based on Tukey's studentised HSD test (honestly significant differences) for assessing the statistical significance of the difference of the mean for each pair of clusters and each season (Table 3).

\subsubsection{Winter season}

During the winter season, both long-range transport from the west and south-west and local pollution episodes lead to enhanced coarse-mode PM mass loadings (Table 2). The contribution of long-range transport to coarse-mode PM loadings varies from $9 \%$ for the south-westerly cluster to $28 \%$ for the medium westerly cluster. Local pollution episodes contribute $14 \%$ on average to the coarse-mode PM observed under calm conditions.

Despite the fact that the average coarse-mode PM varies from $45 \mu \mathrm{g} \mathrm{m}^{-3}$ for the south-easterly cluster to $66 \mu \mathrm{g} \mathrm{m}^{-3}$ for the medium westerly cluster (Fig. 6), the difference of the average is not statistically significant for any of the cluster pairs due to the high intra-cluster variance of coarsemode PM during the winter season (Table 3). Figure 7 shows the correlation of $\mathrm{CO}$ with coarse-mode $\mathrm{PM}\left(\mathrm{PM}_{10-2.5}\right)$ as a function of meteorological conditions. It can be seen from this figure that two sources contribute prominently to coarse-mode PM mass loading during winter: aqueousphase oxidation of gas-phase precursors and dust. Aqueousphase oxidation of gas-phase precursors refers to a process wherein gases (e.g. $\mathrm{NH}_{3}(\mathrm{~g}), \mathrm{SO}_{2}(\mathrm{~g}), \mathrm{NO}_{2}(\mathrm{~g})$ ) are taken up by aqueous-phase aerosol and subsequently undergo reactions that change the oxidation state, resulting in the formation of ammonium, sulfate and nitrate ions. Upon drying, these precipitate out as salts, which can be of coarse mode in size. Aqueous-phase oxidation of gas-phase precursors emitted during combustion leads to a high degree of correlation between coarse-mode particulate matter and $\mathrm{CO}$ at high relative humidity ( $>70 \%, r=0.55$ ), while dust, both dust from long-range transport and locally suspended dust, contributes significantly to coarse-mode $\mathrm{PM}$ at $\mathrm{RH}<50 \%$ and high wind speeds (Fig. 7). The complex interplay of meteorologydependent emissions and oxidation leads to high intra-cluster variance of PM mass loadings and obscures the contribution of long-range transport to PM levels. 

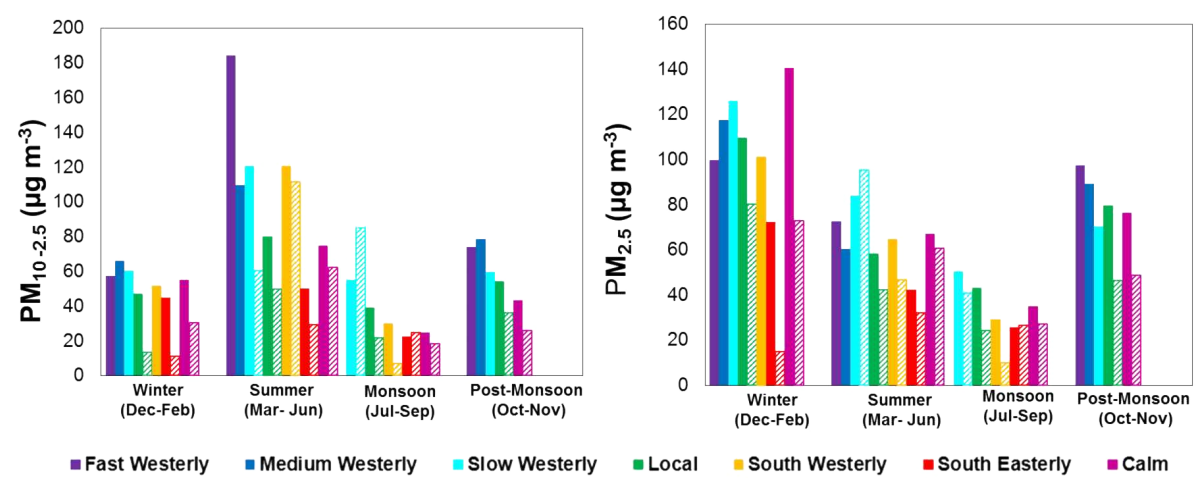

Figure 6. Mean coarse-mode $\left(\mathrm{PM}_{10-2.5}\right)$ and fine-mode $\left(\mathrm{PM}_{2.5}\right)$ mass loading for each air-mass cluster and season at the IISER Mohali air quality station. Hatched bars indicate coarse-mode and fine-mode PM mass loadings observed during rain events.
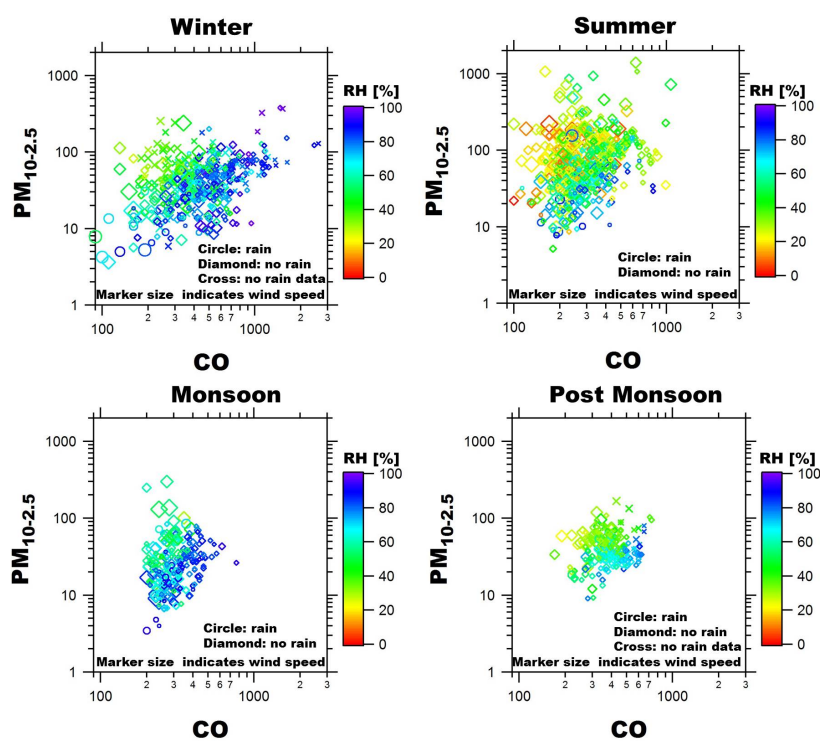

Figure 7. Dependence of coarse-mode PM mass loadings on emission of gas-phase precursors and meteorological parameters for the different seasons. The marker shape distinguishes PM mass loadings measured during rain events (circles) and under dry conditions (diamonds); data points obtained while the rain gauge was not working are marked with crosses. Marker size is proportional to wind speed. The smallest markers indicate $\mathrm{WS} \leq 1 \mathrm{~ms}^{-1}$, the largest markers $\mathrm{WS} \geq 15 \mathrm{~m} \mathrm{~s}^{-1}$. Markers are colour coded with relative humidity.

The influence of wet scavenging on PM mass loadings, however, is statistically significant. During rain events, coarse-mode PM mass loadings drop to $30 \mu \mathrm{g} \mathrm{m}^{-3}$ under calm conditions $(-47 \%), 13 \mu \mathrm{g} \mathrm{m}^{-3}$ for the local cluster $(-72 \%)$ and $11 \mu \mathrm{g} \mathrm{m}^{-3}$ for the south-easterly cluster $(-78 \%)$, and the magnitude of the drop depends only weakly on the total amount of rainfall. Fine PM mass loadings drop to $73 \mu \mathrm{g} \mathrm{m}^{-3}$ under calm conditions $(-48 \%), 80 \mu \mathrm{g} \mathrm{m}^{-3}$ for the local cluster $(-27 \%)$ and $15 \mu \mathrm{g} \mathrm{m}^{-3}$ for the southeasterly cluster $(-80 \%)$. This clearly demonstrates the pro- found influence of wet scavenging on fine-mode PM mass loadings during winter. The percent decrease in fine-mode PM mass loadings during rain events scales perfectly linearly with the total rainfall for each cluster $(1.3 \%$ decrease in $\mathrm{PM}_{2.5}$ per $\mathrm{mm}$ of rainfall, $r^{2}=0.99$ ). The fact that the drop in coarse-mode PM is independent of the total amount of rain while the drop in fine-mode PM strongly depends on the total amount of rainfall could be an indicator that, during wintertime, soluble coarse-mode PM (large salts) plays a crucial role in initiating rainfall as giant cloud condensation nuclei, while fine-mode PM is mostly scavenged by belowcloud scavenging.

For fine-mode PM, local pollution episodes lead to the highest enhancements in fine-mode PM mass loadings $(22 \%)$. Long-range transport from the west contributes only moderately to fine-mode PM ( 7 and $13 \%$ for the medium westerly and slow westerly clusters respectively).

The highest fine-mode PM mass loadings are observed under calm conditions during local pollution episodes $\left(141 \mu \mathrm{g} \mathrm{m}^{-3}\right)$. The enhancement is significant when compared to the south-easterly $\left(72 \mu \mathrm{g} \mathrm{m}^{-3}\right)$, south-westerly $\left(101 \mu \mathrm{g} \mathrm{m}^{-3}\right)$ and fast westerly $\left(100 \mu \mathrm{g} \mathrm{m}^{-3}\right)$ clusters. When only dry days are considered, the difference between local pollution episodes $\left(146 \mu \mathrm{g} \mathrm{m}^{-3}\right.$ on dry days) and the local cluster $\left(110 \mu \mathrm{g} \mathrm{m}^{-3}\right.$ on dry days), which represents the regional air pollution, also becomes significant (Table 3).

The lowest fine-mode PM mass loadings are observed for the south-easterly cluster $\left(72 \mu \mathrm{g} \mathrm{m}^{-3}\right)$ - which is associated with the western disturbance and has significantly lower mass loadings than the local, slow westerly and medium westerly clusters. The fast westerly cluster which is usually observed shortly before a western disturbance establishes itself over India has the second lowest fine-mode mass loadings $\left(100 \mu \mathrm{g} \mathrm{m}^{-3}\right)$, though the difference is not statistically significant with respect to the other clusters due to large intracluster variability in the fine-mode PM mass loadings.

During wintertime, emission of fine-mode particulate matter is driven by combustion. Correlation plots of fine PM with $\mathrm{CO}\left(r^{2}=0.70\right)$, acetonitrile, a biomass combustion tracer 
Table 3. Statistical significance of the difference of the mean for each pair of clusters. Values to the right of the principal diagonal denote significance among $\mathrm{PM}_{10-2.5}$ pairs while values to the left of the principal diagonal denote significance among PM $\mathrm{M}_{2.5}$ pairs. Pairwise comparison based on Tukey's studentised HSD (honestly significant differences) test was used to assess the statistical significance of the difference of the mean for each pair of clusters and each season. Values in brackets indicate the statistical significance after all rain events were removed from the data set.

\begin{tabular}{|c|c|c|c|c|c|c|c|}
\hline & Calm & $\begin{array}{l}\text { South- } \\
\text { easterly }\end{array}$ & $\begin{array}{l}\text { South- } \\
\text { westerly }\end{array}$ & Local & $\begin{array}{l}\text { Slow } \\
\text { westerly }\end{array}$ & $\begin{array}{l}\text { Medium } \\
\text { westerly }\end{array}$ & $\begin{array}{l}\text { Fast } \\
\text { westerly }\end{array}$ \\
\hline & \multicolumn{7}{|c|}{ WINTER (Dec-Feb) } \\
\hline Calm & - & & & & & & \\
\hline South-easterly & $3 \sigma(3 \sigma)$ & - & & & & & \\
\hline South-westerly & $1 \sigma(1 \sigma)$ & & - & & & & \\
\hline Local & $-(1 \sigma)$ & $1 \sigma$ & & - & & & \\
\hline Slow westerly & & $2 \sigma(1 \sigma)$ & & & - & & \\
\hline Medium westerly & & $1 \sigma$ & & & & - & \\
\hline \multirow[t]{2}{*}{ Fast westerly } & $1 \sigma(1 \sigma)$ & & & & & & - \\
\hline & \multicolumn{7}{|c|}{ SUMMER (Mar-Jun) } \\
\hline Calm & - & & & & & & $4 \sigma(3 \sigma)$ \\
\hline South-easterly & $2 \sigma(2 \sigma)$ & - & $2 \sigma(1 \sigma)$ & & $2 \sigma(1 \sigma)$ & $1 \sigma(1 \sigma)$ & $4 \sigma(4 \sigma)$ \\
\hline South-westerly & & $1 \sigma(1 \sigma)$ & - & & & & $1 \sigma(1 \sigma)$ \\
\hline Local & & & & - & & & $4 \sigma(3 \sigma)$ \\
\hline Slow westerly & & $4 \sigma(4 \sigma)$ & $1 \sigma(1 \sigma)$ & $2 \sigma(2 \sigma)$ & - & & $1 \sigma(1 \sigma)$ \\
\hline Medium westerly & & & & & $1 \sigma(1 \sigma)$ & - & $2 \sigma(2 \sigma)$ \\
\hline \multirow[t]{2}{*}{ Fast westerly } & & $2 \sigma(2 \sigma)$ & & & & & - \\
\hline & \multicolumn{7}{|c|}{ MONSOON (Jul-Sep) } \\
\hline Calm & - & & & $1 \sigma$ & $3 \sigma(2 \sigma)$ & & \\
\hline South-easterly & $-(1 \sigma)$ & - & & $1 \sigma(1 \sigma)$ & $4 \sigma(3 \sigma)$ & & \\
\hline South-westerly & & & - & & $2 \sigma(1 \sigma)$ & & \\
\hline Local & & $2 \sigma(2 \sigma)$ & $2 \sigma(1 \sigma)$ & - & $1 \sigma$ & & \\
\hline Slow westerly & $2 \sigma(1 \sigma)$ & $4 \sigma(4 \sigma)$ & $3 \sigma(2 \sigma)$ & & - & & \\
\hline Medium westerly & & & & & & - & \\
\hline \multirow[t]{2}{*}{ Fast westerly } & & & & & & & - \\
\hline & \multicolumn{7}{|c|}{ POST-MONSOON (Oct-Nov) } \\
\hline Calm & - & & & & & $3 \sigma(3 \sigma)$ & $2 \sigma(2 \sigma)$ \\
\hline South-easterly & & - & & & & & \\
\hline South-westerly & & & - & & & & \\
\hline Local & & & & - & & $2 \sigma(1 \sigma)$ & $1 \sigma(1 \sigma)$ \\
\hline Slow westerly & & & & & - & $1 \sigma(1 \sigma)$ & \\
\hline Medium westerly & & & & & $1 \sigma(1 \sigma)$ & - & \\
\hline Fast westerly & $1 \sigma(1 \sigma)$ & & & $1 \sigma(1 \sigma)$ & $2 \sigma(2 \sigma)$ & & - \\
\hline
\end{tabular}

$\left(r^{2}=0.35\right)$, benzene $\left(r^{2}=0.49\right)$ and $\mathrm{NO}_{2}$, a tracer for high temperature combustion $\left(r^{2}=0.43\right)$, Fig. 8 , clearly indicate that, at the receptor site, combustion is the predominant source of wintertime fine-mode PM across all clusters. Due to low ambient temperatures in the winter months, in particular in the surrounding mountain regions, those who cannot afford electric heaters burn dry leaves, wood, coal, agricultural residues and cow dung often mixed with garbage to keep themselves warm. This practice prevails in the whole of South Asia and explains the simultaneous increase in finemode PM and acetonitrile during the winter season. High emissions of benzene have previously been observed during biomass combustion episodes in the region (Sarkar et al., 2013) and inefficient combustion in open fires or simple stoves is known to cause high PM mass loadings (Habib et al., 2004; Venkataraman et al., 2005; Massey et al., 2009; Akagi et al., 2011). While there is a clear correlation between both benzene and acetonitrile and $\mathrm{PM}_{2.5}$, the lower $r^{2}$ for acetonitrile $\left(r^{2}=0.35\right)$ compared to the higher $r^{2}$ for benzene $\left(r^{2}=0.49\right)$ and $\mathrm{CO}\left(r^{2}=0.70\right)$ indicates that mixtures of fuels with variable biomass content are used for domestic heating purposes. The scatter plot between $\mathrm{PM}_{2.5}$ and benzene (Fig. 8) also seems to suggest that there may be regional preferences with respect to the fuel mixture as the emission ratios of the south-easterly cluster usually fall below the fit line, while those for the south-westerly cluster fall above it. The largest scatter and hence variation in fuel type 
Winter (Dec-Feb)
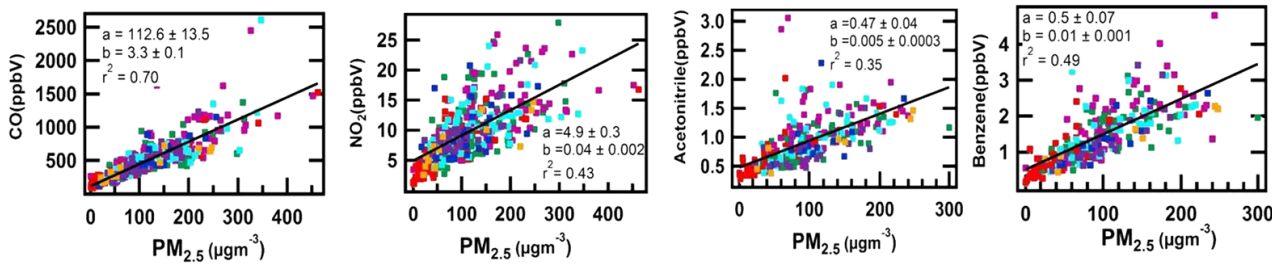

Summer (Mar-Jun)
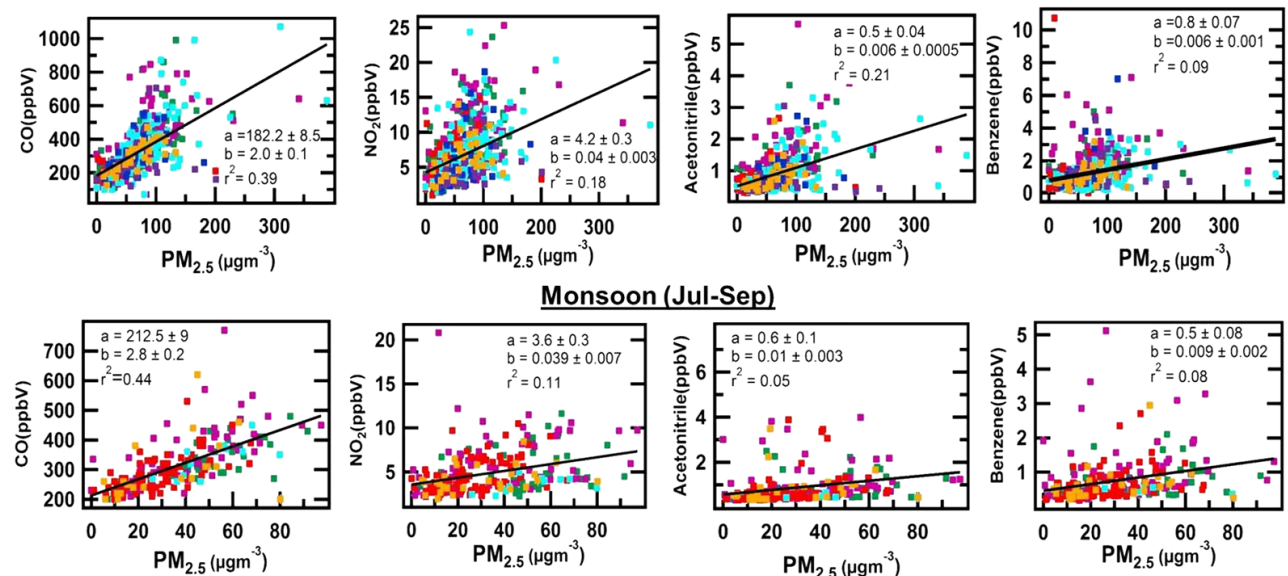

Post-Monsoon (Oct-Nov)
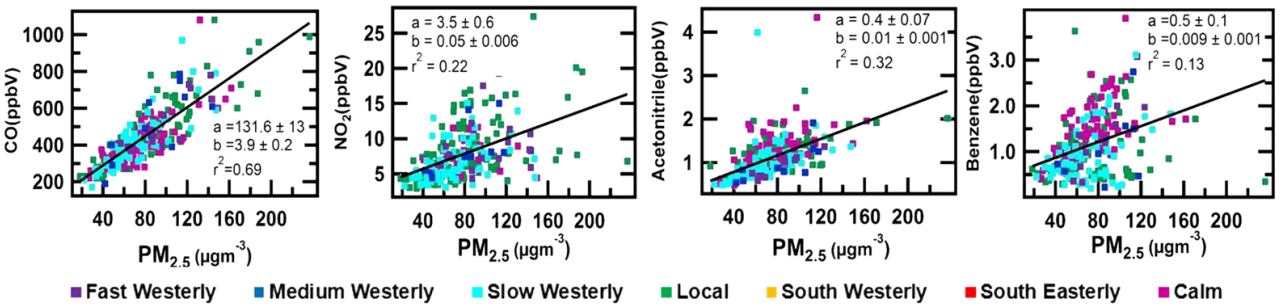

Figure 8. Scatter plots of fine-mode $\mathrm{PM}$ with $\mathrm{CO}$, acetonitrile, benzene and $\mathrm{NO}_{2}$ for the winter, summer, monsoon and post-monsoon seasons. $a$ stands for intercept and $b$ stands for slope in the linear regression equation.

is observed under calm conditions and for the local and slow westerly cluster.

The high mass loading of fine-mode particulate matter coupled with the high relative humidity, which frequently reaches values above $75 \%$, in particular during the night, leads to the formation of persistent fog and haze during wintertime. The uptake of water-soluble organic and inorganic gas-phase species into the aqueous phase and the subsequent chemical reactions result in a fine-mode aerosol that contains a large mass fraction of water-soluble inorganic species (Kumar et al., 2007) and acts as a very efficient cloud condensation nuclei $(\mathrm{CCN})$. Repeated fog processing also leads to the formation of coarse-mode inorganic salt particles (Kulshrestha et al., 1998; Kumar et al., 2007). Kaskaoutis et al. (2013) reported a bi-modal volume size distribution for wintertime aerosol in Kanpur with a first, higher peak between 200 and $300 \mathrm{~nm}$ and a second peak between 3 and $4 \mu \mathrm{m}$ optical equivalent diameter. The ratio of coarse-mode to fine- mode PM observed at our site agrees well with the ratio of coarse-mode to fine-mode PM observed in their study. Kulshrestha et al. (1998) reported a bimodal size distribution peaking at 1 and $5 \mu \mathrm{m}$ aerodynamic equivalent diameter for wintertime aerosol in Agra and found that ammonium sulfates, ammonium nitrate and potassium sulfate dominated water-soluble salts in the fine mode, while sulfates, nitrates and chlorides of sodium, calcium and magnesium dominated coarse-mode aerosol. Dey and Tripathi (2007) reported that in wintertime in Kanpur more than $75 \%$ of coarse-mode particulate matter consisted of water-soluble salts and only less than $25 \%$ of coarse-mode PM consisted of mineral dust. Their findings are in line with our observations that aqueousphase processing of gas-phase precursors is responsible for a significant fraction of coarse-mode PM during the winter season (Fig. 7). 


\subsubsection{Summer season}

During the summer season, long-range transport from the west and south-west contributes significantly to enhanced coarse-mode PM mass loadings (Table 2). Long-range transport contributes approximately $30 \%$ to coarse-mode PM in air masses associated with the south-westerly, slow westerly and medium westerly clusters each and $57 \%$ to coarse-mode PM in air masses associated with the fast westerly cluster.

Air masses associated with the south-easterly cluster $\left(50 \mu \mathrm{g} \mathrm{m}^{-3}\right.$; Fig. 6) show significantly lower coarse-mode PM mass loadings compared to south-westerly, slow westerly, medium and fast westerly clusters and also compared to the local air masses observed under calm conditions. Only the difference with respect to the local cluster $\left(80 \mu \mathrm{g} \mathrm{m}^{-3}\right)$, which represents regional air masses, is not significant, mainly due to the high variance of coarse-mode PM mass loadings of air masses attributed to the local cluster. The variance is caused by convective dust storms (Joseph, 1982). It is very interesting to note that air masses that have crossed the entire, densely populated IGP show the lowest PM mass loadings even when compared with the local cluster, which represents regional air masses or when compared to air masses representing a local fetch region observed under calm conditions $\left(75 \mu \mathrm{g} \mathrm{m}^{-3}\right)$. This is true during both rain events and on dry days.

The highest cluster average is observed for the fast westerly cluster $\left(184 \mathrm{~g} \mathrm{~m} \mathrm{~m}^{-3}\right)$. The coarse-mode PM $\left(\mathrm{PM}_{10-2.5}\right)$ mass loadings for this cluster are significantly enhanced above the coarse-mode PM mass loadings observed in all other clusters and under calm conditions (Table 3), and $57 \%$ of the average PM mass is due to long-range transport for this cluster. The coarse PM enhancement for the fast westerly cluster is associated with dust storms originating in the Middle East that reach our site from the west (Pandithurai et al., 2008).

The slow and medium westerly clusters and the southwesterly cluster show enhanced coarse-mode PM ( $\left.\mathrm{PM}_{10-2.5}\right)$ mass loadings as well, though the difference is statistically significant only with respect to the south-easterly cluster (Table 2). PM enhancements for the south-westerly cluster are associated with dust storms originating from the Thar Desert (Sharma et al., 2012) or the Arabian Peninsula that reach our site through the Indus Valley.

During the summer season, maximum rainfall is observed for the south-easterly, local cluster, south-westerly and slow westerly cluster in descending order of the absolute rainfall amount. Even when rain events, characterised by average coarse-mode PM mass loadings of $50 \mu \mathrm{g} \mathrm{m}^{-3}$ ( $-38 \%$ in average $\mathrm{PM}_{10-2.5}$ mass loading), $29 \mu \mathrm{g} \mathrm{m}^{-3}$ ( $-41 \%$ in average $\mathrm{PM}_{10-2.5}$ mass loading) and $60 \mu \mathrm{g} \mathrm{m}^{-3}$ (-50\% in average $\mathrm{PM}_{10-2.5}$ mass loading) for the local, south-easterly and slow westerly cluster respectively and $62 \mu \mathrm{g} \mathrm{m}^{-3}(-15 \%$ in average $\mathrm{PM}_{10-2.5}$ mass loading) for periods of calm are removed, the differences outlined above remain significant. The south- westerly cluster brings moisture from the Arabian Sea but also dust from the Arabian Peninsula (Pease et al., 1998); consequently, the average coarse-mode PM during rain is comparable to the average coarse-mode PM on dry days. It is interesting to note that the slow westerly cluster shows an increment in fine PM values on rainy days $\left(95 \mathrm{\mu g} \mathrm{m}^{-3}\right)$ as compared to dry days $\left(84 \mu \mathrm{g} \mathrm{m}^{-3}\right)$, indicating that rainfall for this cluster is associated with convective dust storms.

For fine-mode PM, the slow westerly $\left(84 \mu \mathrm{g} \mathrm{m}^{-3}\right)$ cluster shows significantly (Table 3 ) enhanced fine PM mass loadings, and approximately $31 \%$ of the fine PM for this cluster is contributed by transport from the west (Table 2). For the slow westerly cluster, the differences are significant with respect to the south-easterly $\left(42 \mu \mathrm{g} \mathrm{m}^{-3}\right)$, southwesterly $\left(65 \mu \mathrm{g} \mathrm{m}^{-3}\right)$, local $\left(58 \mu \mathrm{g} \mathrm{m}^{-3}\right)$ and medium westerly $\left(60 \mu \mathrm{g} \mathrm{m}^{-3}\right.$; Fig. 6) clusters. Local pollution episodes lead to a $13 \%$ increase above the regional $\mathrm{PM}_{2.5}$ background. For the fast westerly cluster $\left(73 \mu \mathrm{g} \mathrm{m}^{-3}\right), 20 \%$ of the finemode PM is contributed by long-range transport, but the difference is only significant with respect to the south-easterly cluster.

Just like for coarse-mode PM, the lowest fine-mode PM mass loadings are observed for the south-easterly cluster. The difference is significant with respect to the south-westerly, slow westerly and fast westerly cluster and with respect to the local pollution episodes observed under calm conditions (Table 3). Overall fine-mode PM mass loadings in summer are lower than during wintertime.

During the summer season the comparison of the emission ratios of acetonitrile, benzene, $\mathrm{CO}$ and $\mathrm{NO}_{2}$ with finemode particulate matter patterns indicate that several sources drive fine-mode PM (Fig. 8). While there is still a reasonable correlation between $\mathrm{CO}$ and $\mathrm{PM}_{2.5}\left(r^{2}=0.39\right)$, most other combustion tracers have a poor coefficient of correlation with $\mathrm{PM}_{2.5}$. The scatter plots indicate a spread between at least two types of combustion. One type is characterised by high acetonitrile, benzene and $\mathrm{NO}_{2}$ emissions but fairly low $\mathrm{PM}_{2.5}$ mass loadings and is probably associated with wheat residue burning in Punjab, while the other type is characterised by lower benzene, $\mathrm{NO}_{2}$ and acetonitrile mixing ratios but higher $\mathrm{PM}_{2.5}$ mass. This second source is probably traffic, which in arid regions during the summer season is responsible for significant (re-)suspension of dust in particular when wind speeds are high $\left(>5 \mathrm{~m} \mathrm{~s}^{-1}\right)$.

Several authors reported that during the summer season, coarse-mode mineral dust with a single peak at 3-4 $\mu \mathrm{m}$ optical equivalent diameter dominates PM mass loadings in the IGP (Gautam et al., 2011; Kaskaoutis et al., 2013); however, we find that fine-mode particulate matter $\left(\mathrm{PM}_{2.5}\right)$ contributes almost equally to PM mass loadings, and a significant fraction of $\mathrm{PM}_{2.5}$ mass is still combustion derived. Only Jethva et al. (2005), reported a bimodal volume distribution for dust storms, with one peak at 3-4 $\mu \mathrm{m}$ and a second peak at $1.5 \mu \mathrm{m}$, which agrees well with our findings. The peak at $1.5 \mu \mathrm{m}$ corresponds to the clay fraction of mineral dust and is frequently 
found to be strongly enriched in mineral dust plumes after extended long-range transport (Pöschl et al., 2010). At our site, we find that the coarse-mode PM fraction in individual dust storm events varies between 45 and $92 \%$, with the highest coarse-mode fraction typically recorded for dust storms originating in the Thar Desert. While during dust storms windblown dust contributes significantly to fine-mode PM, $\mathrm{PM}_{2.5}$ is usually dominated by combustion-derived aerosols at our site (Fig. 8).

\subsubsection{Monsoon season}

During the monsoon season, the effect of wet scavenging of coarse-mode PM mass loadings can be clearly seen in the low average coarse PM mass loadings. Qualitatively, the average mass loading is anti-correlated with rainfall. The lowest coarse-mode PM mass loadings are observed for the southeasterly $\left(22 \mu \mathrm{g} \mathrm{m}^{-3}\right)$ and south-westerly $\left(30 \mu \mathrm{g} \mathrm{m}^{-3}\right)$ clusters.

The slow westerly cluster $\left(55 \mu \mathrm{g} \mathrm{m}^{-3}\right)$ shows significant enhancement over all other clusters and the calm periods. Long-range transport from the west contributes approximately $30 \%$ to enhanced coarse-mode PM mass loadings in the slow westerly cluster (Table 2). However, when rain events are removed, the enhancement over the local cluster is no longer significant.

The local cluster $\left(39 \mu \mathrm{g} \mathrm{m}^{-3}\right)$ shows enhancements over the south-easterly cluster $\left(22 \mu \mathrm{g} \mathrm{m}^{-3}\right)$ and periods with calm conditions ( $25 \mu \mathrm{g} \mathrm{m}^{-3}$ ); however, the enhancement over calm conditions is no longer significant when rain events with average coarse-mode PM mass loadings of 22, 25 and $18 \mu \mathrm{g} \mathrm{m}^{-3}$ respectively are removed from the three clusters (Fig. 6, Table 3).

During monsoon seasons, most coarse-mode PM is derived from aqueous-phase oxidation of gas-phase precursors (Fig. 7), a process that is extremely efficient at $\mathrm{RH}>75 \%$, and the removal is controlled by wet scavenging. Dust storms contribute only occasionally to coarse-mode PM.

For fine-mode $\mathrm{PM}\left(\mathrm{PM}_{2.5}\right)$, the south-easterly cluster $\left(26 \mu \mathrm{g} \mathrm{m}^{-3}\right)$ shows the lowest mass loadings. The difference is significant with respect to the local $\left(43 \mu \mathrm{g} \mathrm{m}^{-3}\right)$ and slow westerly $\left(51 \mathrm{~g} \mathrm{~m}^{-3}\right)$ clusters (Fig. 6). The difference between south-easterly cluster and calm pollution episodes becomes significant when only dry days with an average fine PM loading of 26 and $38 \mu^{-3} \mathrm{~m}^{-3}$ respectively are considered (Table 3$)$. The south-westerly cluster $\left(29 \mu \mathrm{g} \mathrm{m}^{-3}\right)$, too, shows significantly lower fine-mode PM when compared to the local $\left(43 \mu \mathrm{g} \mathrm{m}^{-3}\right)$ and slow westerly $\left(51 \mu \mathrm{g} \mathrm{m}^{-3}\right)$ clusters (Fig. 6). The slow westerly cluster shows significant enhancements of fine-mode PM over all other clusters except the local cluster and significant enhancement over calm periods. Transport contributes approximately $15 \%$ to the finemode PM for this cluster.

During the monsoon season, the correlation of acetonitrile, benzene, $\mathrm{CO}$ and $\mathrm{NO}_{2}$ with fine-mode particulate mat- ter indicates that multiple combustion sources drive finemode PM (Fig. 8). While there is still correlation with $\mathrm{CO}$ $\left(r^{2}=0.44\right)$, the coefficient of correlation of acetonitrile, benzene and $\mathrm{NO}_{2}$ with $\mathrm{PM}_{2.5}$ is low, and the largest scatter due to biomass combustion derived $\mathrm{PM}_{2.5}$ (associated with high acetonitrile, benzene and $\mathrm{NO}_{2}$ ) is observed under calm conditions. $\mathrm{PM}_{2.5}$ enhancements for the slow westerly cluster, on the other hand, are accompanied by low acetonitrile, benzene and $\mathrm{NO}_{2}$ mixing ratios and are possibly caused by traffic.

\subsubsection{Post-monsoon season}

During the post-monsoon season, air masses reaching the site from the west (slow, medium and fast westerly clusters) show higher coarse PM mass loadings compared to the local cluster and air masses observed under calm conditions. Transport from the west contributes approximately $30 \%$ each to the coarse-mode PM mass loadings of the medium westerly and fast westerly clusters and approximately $10 \%$ to the coarsemode PM mass loadings of the slow westerly cluster. The highest coarse-mode PM is observed for the fast and medium westerly clusters.

The enhancement in coarse-mode PM observed for the medium westerly cluster is statistically significant with respect to all other clusters, including the slow westerly cluster. The enhancement observed for the fast westerly cluster is statistically significant only with respect to the local cluster and calm conditions. Results remain significant even when rain events are removed from both.

Calm episodes have significantly lower coarse-mode PM mass loadings $\left(43 \mu \mathrm{g} \mathrm{m}^{-3}\right)$ than the medium and fast westerly clusters, indicating that local pollution episodes are not a significant source of coarse-mode PM during the postmonsoon season, while the fetch regions of the westerly clusters are.

The highest fine-mode PM during the post-monsoon season is observed in the fast westerly cluster $\left(97 \mu \mathrm{g} \mathrm{m}^{-3}\right)$ and transport contributes $18 \%$ to the PM mass loading associated with this cluster (Table 2). Fine PM mass loadings for this cluster are significantly enhanced compared to calm conditions $\left(76 \mu \mathrm{g} \mathrm{m}^{-3}\right)$ and the local $\left(80 \mu \mathrm{g} \mathrm{m}^{-3}\right)$ and slow westerly $\left(70 \mu \mathrm{g} \mathrm{m}^{-3}\right)$ clusters. All differences discussed above remain significant when rain events are removed from the data set and only dry days are considered. The second highest fine-mode PM mass loadings are observed for the medium westerly cluster. Transport contributes $11 \%$ to the PM mass loadings observed for this cluster and the source characteristics are similar to those observed for the fast westerly cluster (Fig. 8).

For the slow westerly and local clusters, smoke produced by crop residue burning is a major source of PM during this season as crop residue burning is practised in most of Punjab. Consequently, all air masses reaching the receptor site from the west are impacted by this source. Air masses attributed to the slow westerly and local clusters and air masses observed 
under calm conditions show a clear enhancement in the PM to acetonitrile ratio above the line fit representing the regional background on days when fresh crop residue burning plumes impact the site. Paddy residue burning leads to massive enhancements in acetonitrile and benzenoids (Sarkar et al., 2013) and equally large emissions of PM. Singh et al. (2010) reported monthly average SPM of $400-500 \mu \mathrm{g} \mathrm{m}^{-3}$ for a village site near Patiala during October and November and monthly average SPM of $300-400 \mu \mathrm{g} \mathrm{m}^{-3}$ at a suburban site (residential campus of Punjab University) during the same 2 months. At our suburban receptor site further downwind of the burning fields, we find that $\mathrm{PM}_{10}$ generally ranges between 100 and $200 \mu \mathrm{g} \mathrm{m}^{-3}$ and exceeds $200 \mu \mathrm{g} \mathrm{m}^{-3}$ only during a few episodes. Badrinath et al. (2009) showed that the crop residue burning smoke is mostly channelled into the IGP and Mishra and Shibata (2012) showed that the crop residue burning plumes impact sites as far downwind as Kanpur. During its journey, the smoke ages and aerosol size distributions are modified. Kaskaoutis et al. (2013) reported a bimodal volume size distribution for post-monsoon aerosol in Kanpur with a first peak between 200 and $300 \mathrm{~nm}$ and a second peak at 3-4 $\mu \mathrm{m}$. In Kanpur, coarse-mode aerosol exceeded fine-mode PM (by a factor of 1.3), while at our receptor site closer to the burning fields, fine-mode PM exceeds coarse-mode PM by a factor of 1.5 . This indicates that during the $720 \mathrm{~km}$ journey from Punjab to Kanpur approximately $30 \%$ of the fine particulate matter mass is transformed into coarse-mode PM through repeated fog processing.

\subsection{Impact of air-mass transport on particulate matter (PM) exceedance events}

The mean PM mass loadings of an air-mass cluster represent a poor proxy for the number of exceedance events, that is, the number of days on which the $24 \mathrm{~h}$ average of $\mathrm{PM}_{2.5}$ or $\mathrm{PM}_{10}$ exceeded the NAAQS of $60 \mu \mathrm{g} \mathrm{m}^{-3}$ for $24 \mathrm{~h}$ average $\mathrm{PM}_{2.5}$ or $100 \mu \mathrm{g} \mathrm{m}^{-3}$ for the $24 \mathrm{~h}$ average $\mathrm{PM}_{10}$ respectively. During the winter season on $\sim 160$ days (out of 180 days), the NAAQS of both $\mathrm{PM}_{10}$ and $\mathrm{PM}_{2.5}$ was exceeded. For the summer season, exceedance days associated with $\mathrm{PM}_{10}$ were more frequent (203 out of 243 days) than those associated with $\mathrm{PM}_{2.5}$ (157 out of 243). During the monsoon season, the receptor site received cleaner air masses, with only 13 and 21 exceedance days (out of 92) of $\mathrm{PM}_{2.5}$ and $\mathrm{PM}_{10}$ respectively. The post-monsoon season had frequent exceedance days with NAAQS of $\mathrm{PM}_{10}$ and $\mathrm{PM}_{2.5}$ being exceeded on $\sim 110$ out of 114 days. While individual pollution episodes with extremely high PM mass loadings such as dust storms can profoundly influence the cluster mean, they barely affect the number of exceedance days, as such events are rare.

\subsubsection{Winter season}

During the winter season, emissions of gas-phase precursors and particulate matter from local and regional sources are so high, and the conversion of gas-phase precursors to both $\mathrm{PM}_{2.5}$ and $\mathrm{PM}_{10}$ is so efficient, that the NAAQS for both $\mathrm{PM}_{2.5}$ and $\mathrm{PM}_{10}$ is exceeded $95 \%$ (Fig. 9) of the days associated with the local cluster, i.e. air masses that had been confined over the NW-IGP 3 days prior to their arrival at the receptor site. Despite the fact that transport from the west does enhance $\mathrm{PM}_{10}$ mass loadings for the slow, medium and fast westerly clusters, it increased the fraction of days during which PM mass loadings exceed the NAAQS by a maximum of $5 \%$. The largest increase in the fraction of exceedance days is observed for the south-westerly and medium westerly clusters (from 95 to $100 \%$ of the days associated with this synoptic-scale transport for both $\mathrm{PM}_{2.5}$ and $\mathrm{PM}_{10}$ ) and the slow westerly cluster (from 95 to $100 \%$ for $\mathrm{PM}_{10}$ ). Significantly cleaner air masses with a lower fraction of exceedance events are usually associated with wet scavenging and/or air masses brought by a western disturbance (south-easterly cluster: $56 \%$ of the days associated with this synoptic-scale transport for $\mathrm{PM}_{2.5}$ and $58 \%$ for $\mathrm{PM}_{10}$ ). Calm conditions on the other hand do not increase the percentage of exceedance days for either $\mathrm{PM}_{10}$ or $\mathrm{PM}_{2.5}$ when compared to the local cluster.

\subsubsection{Summer season}

As discussed in Sect. 3.3.2, during the summer season, the ambient RH is usually $<60 \%$ at night and 20-30\% during the day (Table 1), and aqueous-phase oxidation contributes less to $\mathrm{PM}_{2.5}$ and $\mathrm{PM}_{10}$ mass loadings. Instead, PM mass is dominated by direct emissions, dust and photochemistry.

Despite frequent dust storms, exceedance events are less frequent during the summer season than they are during the winter season. The NAAQS for $\mathrm{PM}_{10}$ is exceeded on $80 \%$ of the days associated with the local cluster and the NAAQS for $\mathrm{PM}_{2.5}$ is exceeded on $70 \%$ of the days associated with this synoptic-scale transport. While dust storms - episodic events during which $\mathrm{PM}_{10}$ mass loadings can reach up to $3000 \mu \mathrm{g} \mathrm{m}^{-3}$ - have a strong impact on the cluster mean, in particular for the fast westerly cluster, they barely affect the number of exceedance events. This is particularly true for the fast and medium westerly clusters. Only for the south-westerly cluster do dust storms increase the number of exceedance events compared to the local cluster, from 80 to $100 \%$ of the days associated with this synoptic-scale transport for $\mathrm{PM}_{10}$. The highest increase in the number of exceedance events for $\mathrm{PM}_{2.5}$ is observed for the slow westerly cluster, which is most strongly affected by wheat residue burning in Punjab. Wheat residue burning increases the number of exceedance events observed for the slow westerly cluster compared to the local cluster from 70 to $80 \%$ of the days associated with this synoptic-scale transport for $\mathrm{PM}_{2.5}$, and from 80 to $95 \%$ for $\mathrm{PM}_{10}$. The fraction of exceedance events for the south-easterly cluster, both for $\mathrm{PM}_{10}$ and $\mathrm{PM}_{2.5}$ (50 and $30 \%$ of the days with this synoptic-scale transport respectively), is associated with cleaner air masses reaching the 

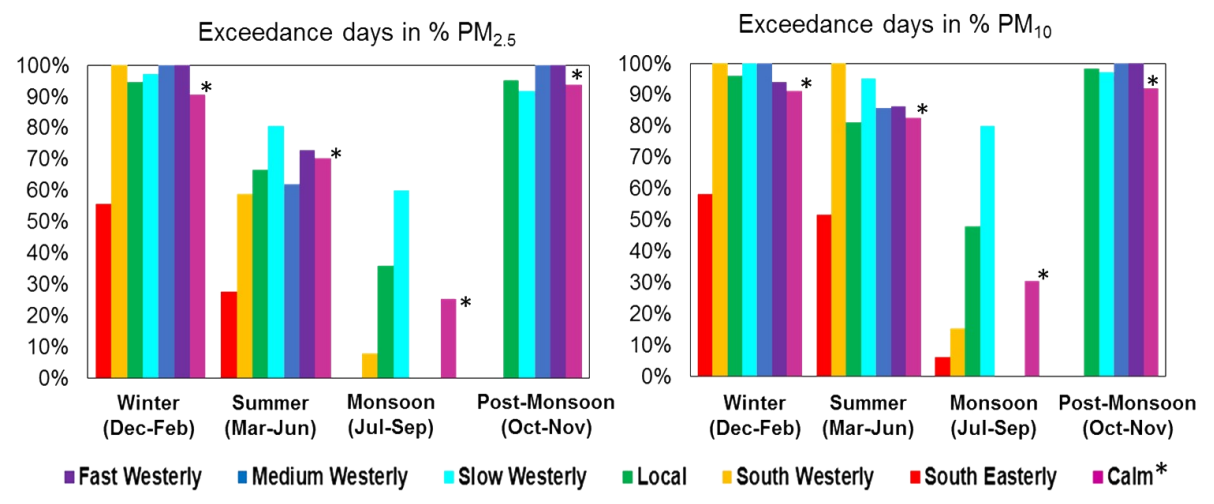

Figure 9. Percentage of days where the $24 \mathrm{~h}$ average $\mathrm{PM}_{10}$ and $\mathrm{PM}_{2.5}$ mass loading (in $\mu \mathrm{g} \mathrm{m}^{-3}$ ) exceed the national ambient air quality standard for each air-mass cluster and season. ${ }^{*}$ For calm conditions, $\mathrm{PM}_{2.5}$ or $\mathrm{PM}_{10}$ were averaged for all times during a $24 \mathrm{~h}$ interval that had WS $<1 \mathrm{~m} \mathrm{~s}^{-1}$ only. The fraction of exceedance days is calculated based on this average, and is not based on a genuine $24 \mathrm{~h}$ average, as wind speeds do not remain low continuously.

receptor site from the eastern IGP. Calm conditions barely increase the number of exceedance days.

\subsubsection{Monsoon season}

Figure 9 shows that the frequency of $\mathrm{PM}_{2.5}$ exceedance days for each cluster is anti-correlated with the total rainfall observed for the respective cluster. For the local cluster, the NAAQS for $\mathrm{PM}_{10}$ is exceeded on $48 \%$ of the days and the NAAQS for $\mathrm{PM}_{2.5}$ is exceeded on $36 \%$ of the days associated with this synoptic-scale transport. The slow westerly cluster which is associated with occasional dust storms increases the percentage of exceedance days from 36 to $60 \%$ for $\mathrm{PM}_{2.5}$ and from 48 to $80 \%$ for $\mathrm{PM}_{10}$. The fraction of exceedance events for the south-easterly cluster, both for $\mathrm{PM}_{10}(6 \%$ of the days associated with this synoptic-scale transport) and $\mathrm{PM}_{2.5}(0 \%$ of the days associated with this synoptic-scale transport), is associated with extremely clean air masses reaching the receptor site from the eastern IGP.

\subsubsection{Post-monsoon season}

As discussed in Sect. 3.3.4, crop residue burning coupled with aqueous-phase oxidation of gas-phase precursors is responsible for high PM mass loading during the postmonsoon season. It can be seen from Fig. 9 that it also contributes to a high frequency of exceedance events. The NAAQS for both $\mathrm{PM}_{2.5}$ and $\mathrm{PM}_{10}$ is exceeded on 90-100\% of the days associated with the synoptic-scale transport for the local, slow westerly, medium westerly, and fast westerly clusters and under calm conditions. Transport barely leads to an increase in the fraction of exceedance days.

\section{Conclusions}

We investigated the contribution of long-range transport and local pollution episodes to the average coarse- and fine-mode
PM mass loadings at our receptor site using 2 years of high temporal resolution data. The study yielded several results as follows.

1. Long-range transport from the west (source regions: Arabia, Thar Desert, Middle East and Afghanistan) leads to significant enhancements in the average coarsemode PM mass loadings during all seasons. The contribution of long-range transport from this source region to coarse-mode PM varied between 9 and $57 \%$ of the total $\mathrm{PM}_{10-2.5}$ mass.

2. For fine-mode PM, the situation is more complex. The fast westerly cluster is associated with a $20 \%$ increase in fine-mode PM during the summer and post-monsoon seasons but cleaner air masses during the winter season. The medium westerly cluster shows moderately enhanced PM mass loadings during all seasons, while slow westerly transport leads to enhanced $\mathrm{PM}_{2.5}$ mass loadings during the winter, summer and monsoon seasons, but not during the post-monsoon season.

3. Local pollution episodes (wind speed $<1 \mathrm{~m} \mathrm{~s}^{-1}$ ) contributed to enhanced $\mathrm{PM}_{2.5}$ mass loadings during both the winter and summer season and to enhanced coarsemode PM only during the winter season.

4. The south-easterly cluster (source region: eastern IGP) is associated with significantly lower fine- and coarsemode PM mass loadings during all seasons.

5. The number of days during which PM mass loadings exceed the national ambient air quality standard (NAAQS) of $100 \mu \mathrm{g} \mathrm{m}^{-3}$ for $24 \mathrm{~h}$ average $\mathrm{PM}_{10}$ and $60 \mu \mathrm{g} \mathrm{m}^{-3}$ for $24 \mathrm{~h}$ average $\mathrm{PM}_{2.5}$ (NAAQS, 2009), however, is controlled by long-range transport to a much lesser degree.

For the local cluster, which represents regional air masses (source region: NW-IGP), the fraction of days 
during which the national ambient air quality standard (NAAQS) of $60 \mathrm{\mu g} \mathrm{m}^{-3}$ for $24 \mathrm{~h}$ average $\mathrm{PM}_{2.5}$ was exceeded varied between $36 \%$ of the days associated with this synoptic-scale transport during the monsoon season and $95 \%$ during the winter and post-monsoon seasons respectively; the fraction of days during which the national ambient air quality standard (NAAQS) of $100 \mu \mathrm{g} \mathrm{m}^{-3}$ for the $24 \mathrm{~h}$ average $\mathrm{PM}_{10}$ was exceeded varied between $48 \%$ during the monsoon season and $98 \%$ during the post-monsoon season.

6. Long-range transport was responsible for bringing both air masses with a significantly lower fraction of exceedance days from the eastern IGP and air masses with a moderate increase in the fraction of exceedance days from the west (source regions: Arabia, Thar Desert, Middle East and Afghanistan). The south-easterly cluster (source region: eastern IGP) is always associated with a significantly lower fraction of exceedance days and the south-westerly cluster also leads to a lower fraction of exceedance days during the monsoon season.

Whenever long-range transport increases the fraction of exceedance days, the increase varies between a few percent and at most $20 \%$.

7. Fine-mode PM $\left(\mathrm{PM}_{2.5}\right)$ contributes most to PM exceedance events at a regional level and $\mathrm{PM}_{2.5}$ mass loadings are largely controlled by combustion sources during all seasons. Primary emission and gas to particle conversion of gas-phase precursors emitted during the combustion both contribute to the final mass loadings in varying proportions.

In order to bring PM mass loadings into compliance with the national ambient air quality standard (NAAQS) and to reduce the number of exceedance days, mitigation of regional combustion sources needs to be given highest priority as the number of exceedance days for air masses associated with the source region NW-IGP is already extremely high.

To devise efficient mitigation strategies targeted at bringing down the number of PM exceedance events, a larger set of tracers needs to be incorporated and alternate source receptor modelling approaches, e.g. PMF modelling targeted specifically towards identifying local and regional combustion sources contributing towards the emissions of PM and towards the emission gas-phase aerosol precursors, need to be adopted.

The Supplement related to this article is available online at doi:10.5194/acp-15-9501-2015-supplement.
Acknowledgements. We thank the IISER Mohali Atmospheric Chemistry Facility for data and the Ministry of Human Resource Development (MHRD), India, and IISER Mohali for funding the facility.

We thank the NOAA Air Resources Laboratory (ARL) for the provision of the HYSPLIT transport and dispersion model used in this study. We thank the ESA GlobCover 2009 project (ESA 2010 and UCLouvain) for providing a high-resolution land classification map of the region.

Harshita Pawar, Himanshu Sachan and Vinod Kumar gratefully acknowledge a DST Inspire fellowship, Boggarapu Prafulla Chandra acknowledges a CSIR-JRF fellowship and Ruhani Arya gratefully acknowledges the IISER Mohali summer research fellowship programme. Boggarapu Praphulla Chandra, Chinmoy Sarkar and Saryu Garg acknowledge a 6-month project assistant position funded by the DST - Max Planck Research Partner Group on "Tropospheric OH reactivity and VOC measurements".

Edited by: J. West

\section{References}

Abdalmogith, S. S. and Harrison, R. M.: The use of trajectory cluster analysis to examine the long-range transport of secondary inorganic aerosol in the UK, Atmos. Environ., 39, 6686-6695, doi:10.1016/j.atmosenv.2005.07.059, 2005.

Agnihotri, C. and Singh, M.: Satellite study of western disturbances, Mausam, 33, 249-254, 1982.

Akagi, S. K., Yokelson, R. J., Wiedinmyer, C., Alvarado, M. J., Reid, J. S., Karl, T., Crounse, J. D., and Wennberg, P. O.: Emission factors for open and domestic biomass burning for use in atmospheric models, Atmos. Chem. Phys., 11, 4039-4072, doi:10.5194/acp-11-4039-2011, 2011.

Badarinath, K., Kharol, S. K., Sharma, A. R., and Krishna Prasad, V.: Analysis of aerosol and carbon monoxide characteristics over Arabian Sea during crop residue burning period in the Indo-Gangetic Plains using multi-satellite remote sensing datasets, J. Atmos. Sol.-Terr. Phy., 71, 1267-1276, 2009.

Bell, M. L. and Davis, D. L.: Reassessment of the lethal London fog of 1952: novel indicators of acute and chronic consequences of acute exposure to air pollution, Environ. Health Persp., 109, 389-394, 2001.

Bhat, G. S.: The Indian drought of 2002 a sub-seasonal phenomenon?, Q. J. Roy. Meteor. Soc., 132, 2583-2602, doi:10.1256/qj.05.13, 2006.

Borge, R., Lumbreras, J., Vardoulakis, S., Kassomenos, P., and Rodríguez, E.: Analysis of long-range transport influences on urban $\mathrm{PM}_{10}$ using two-stage atmospheric trajectory clusters, Atmos. Environ., 41, 4434-4450, doi:10.1016/j.atmosenv.2007.01.053, 2007.

Bow, S.-T.: Pattern Recognition: Application to Large Data-Set Problems, Marcel Dekker Inc., New York, 1984.

Brankov, E., Rao, S. T., and Porter, P. S.: A trajectory-clusteringcorrelation methodology for examining the long-range transport of air pollutants, Atmos. Environ., 32, 1525-1534, doi:10.1016/S1352-2310(97)00388-9, 1998. 
Bryson, R. A. and Swain, A. M.: Holocene variations of monsoon rainfall in Rajasthan, Quaternary Res., 16, 135-145, doi:10.1016/0033-5894(81)90041-7, 1981.

Buchanan, C. M., Beverland, I. J., and Heal, M. R.: The influence of weather-type and longrange transport on air particle concentrations in Edinburgh, U K., Atmos. Environ., 36, 5343-5354, 2002.

Das, P. K.: Mean vertical motion and non-adiabatic heat sources over India during the monsoon, Tellus, 14, 212-220, doi:10.1111/j.2153-3490.1962.tb00132.x, 1962.

Dey, S. and Tripathi, S.: Estimation of aerosol optical properties and radiative effects in the Ganga basin, northern India, during the wintertime, J. Geophys. Res.-Atmos., 112, D03203, doi:10.1029/2006jd007267, 2007.

Dimri, A. P.: Impact of horizontal model resolution and orography on the simulation of a western disturbance and its associated precipitation, Meteorol. Appl., 11, 115-127, doi:10.1017/S1350482704001227, 2004.

Dockery, D. W., Speizer, F. E., Stram, D. O., Ware, J. H., Spengler, J. D., and Ferris Jr., B. G.: Effects of inhalable particles on respiratory health of children, Am. Rev. Respir. Dis., 139, 587594, 1989.

Dockery, D. W., Pope, C. A., Xu, X., Spengler, J. D., Ware, J. H., Fay, M. E., Ferris Jr, B. G., and Speizer, F. E.: An association between air pollution and mortality in six US cities, New Engl. J. Med., 329, 1753-1759, 1993.

Dorling, S. R., Davies, T. D., and Pierce, C. E.: Cluster analysis: a technique for estimating the synoptic meteorological controls on air and precipitation chemistry - Method and applications, Atmos. Environ. A-Gen., 26, 2575-2581, doi:10.1016/09601686(92)90110-7, 1992.

Draxler, R. and Rolph, G.: HYSPLIT (HYbrid Single-Particle Lagrangian Integrated Trajectory) NOAA Air Resources Laboratory, College Park, MD, Model access via NOAA ARL READY Website, 2013.

Draxler, R. R. and Hess, G.: An overview of the HYSPLIT_4 modelling system for trajectories, Aust. Meteorol. Mag., 47, 295308, 1998

Englert, N.: Fine particles and human health - a review of epidemiological studies, Toxicol. Lett., 149, 235-242, 2004.

Firket, J.: The cause of the symptoms found in the Meuse Valley during the fog of December, 1930, Bull. Acad. R. Med. Belg., 11, 683-741, 1931.

Fleming, Z. L., Monks, P. S., and Manning, A. J.: Review: Untangling the influence of air-mass history in interpreting observed atmospheric composition, Atmos. Res., 104-105, 1-39, doi:10.1016/j.atmosres.2011.09.009, 2012.

Gautam, R., Hsu, N. C., Tsay, S. C., Lau, K. M., Holben, B., Bell, S., Smirnov, A., Li, C., Hansell, R., Ji, Q., Payra, S., Aryal, D., Kayastha, R., and Kim, K. M.: Accumulation of aerosols over the Indo-Gangetic plains and southern slopes of the Himalayas: distribution, properties and radiative effects during the 2009 pre-monsoon season, Atmos. Chem. Phys., 11, 12841-12863, doi:10.5194/acp-11-12841-2011, 2011.

Goswami, B. N.: Interannual variations of indian summer monsoon in a GCM: external conditions versus internal feedbacks, J. Climate, 11, 501-522, doi:10.1175/15200442(1998)011<0501:IVOISM>2.0.CO;2, 1998.
Goswami, B. N., Venugopal, V., Sengupta, D., Madhusoodanan, M. S., and Xavier, P. K.: Increasing trend of extreme rain events over india in a warming environment, Science, 314, 1442-1445, doi:10.1126/science.1132027, 2006a.

Goswami, B. N., Wu, G., and Yasunari, T.: The annual cycle, intraseasonal oscillations, and roadblock to seasonal predictability of the asian summer monsoon, J. Climate, 19, 5078-5099, doi:10.1175/JCLI3901.1, 2006b.

Grivas, G., Chaloulakou, A., and Kassomenos, P.: An overview of the $\mathrm{PM}_{10}$ pollution problem, in the Metropolitan Area of Athens, Greece, assessment of controlling factors and potential impact of long range transport, Sci. Total Environ., 389, 165177, doi:10.1016/j.scitotenv.2007.08.048, 2008.

Habib, G., Venkataraman, C., Shrivastava, M., Banerjee, R., Stehr, J., and Dickerson, R. R.: New methodology for estimating biofuel consumption for cooking: atmospheric emissions of black carbon and sulfur dioxide from India, Global Biogeochem. Cy., 18, GB3007, doi:10.1029/2003gb002157, 2004.

Jethva, H., Satheesh, S. K., and Srinivasan, J.: Seasonal variability of aerosols over the Indo-Gangetic basin, J. Geophys. Res., 110, D21204, doi:10.1029/2005JD005938, 2005.

Joseph, P.: A tentative model of Andhi, Mausam, 33, 417-422, 1982.

Joseph, P. and Raman, P.: Existence of low level westerly jet stream over peninsular India during July, Indian J. Meteorol. Geophys., 17, 407-410, 1966.

Joseph, P. V. and Sijikumar, S.: Intraseasonal Variability of the Low-Level Jet Stream of the Asian Summer Monsoon, J. Climate, 17, 1449-1458, doi:10.1175/15200442(2004)017<1449:IVOTLJ>2.0.CO;2, 2004.

Kappos, A. D., Bruckmann, P., Eikmann, T., Englert, N., Heinrich, U., Höppe, P., Koch, E., Krause, G. H., Kreyling, W. G., and Rauchfuss, K.: Health effects of particles in ambient air, Int. J. Hyg. Envir. Heal., 207, 399-407, 2004.

Kaskaoutis, D., Sinha, P., Vinoj, V., Kosmopoulos, P., Tripathi, S., Misra, A., Sharma, M., and Singh, R.: Aerosol properties and radiative forcing over Kanpur during severe aerosol loading conditions, Atmos. Environ., 79, 7-19, 2013.

Kassomenos, P., Vardoulakis, S., Borge, R., Lumbreras, J., Papaloukas, C., and Karakitsios, S.: Comparison of statistical clustering techniques for the classification of modelled atmospheric trajectories, Theor. Appl. Climatol., 102, 1-12, doi:10.1007/s00704-009-0233-7, 2010.

Kaushik, C., Ravindra, K., Yadav, K., Mehta, S., and Haritash, A.: Assessment of ambient air quality in urban centres of Haryana (India) in relation to different anthropogenic activities and health risks, Environ. Monit. Assess., 122, 27-40, 2006.

Kulshrestha, U. C., Saxena, A., Kumar, N., Kumari, K. M., and Srivastava, S. S.: Chemical composition and association of size-differentiated aerosols at a suburban site in a semi-arid tract of India, J. Atmos. Chem., 29, 109-118, doi:10.1023/A:1005796400044, 1998.

Kumar, R., Srivastava, S., and Kumari, K. M.: Characteristics of aerosols over suburban and urban site of semiarid region in India: seasonal and spatial variations, Aerosol Air Qual. Res., 7, 531549, 2007. 
Lang, T. J. and Barros, A. P.: Winter storms in the Central Himalayas, J. Meteorol. Soc. Jpn., 82, 829-844, doi:10.2151/jmsj.2004.829, 2004.

Lawrence, M. G. and Lelieveld, J.: Atmospheric pollutant outflow from southern Asia: a review, Atmos. Chem. Phys., 10, 1101711096, doi:10.5194/acp-10-11017-2010, 2010.

Logan, W.: Mortality in the London fog incident, 1952, Lancet, 261, 336-338, 1953.

Massey, D., Masih, J., Kulshrestha, A., Habil, M., and Taneja, A.: Indoor/outdoor relationship of fine particles less than $2.5 \mu \mathrm{m}$ $\left(\mathrm{PM}_{2.5}\right)$ in residential homes locations in central Indian region, Build. Environ., 44, 2037-2045, 2009.

Miller, L., Farhana, S., and Xu, X.: Trans-boundary air pollution in Windsor, Ontario (Canada), Procedia Environmental Sciences, 2, 585-594, doi:10.1016/j.proenv.2010.10.064, 2010.

Mishra, A. K. and Shibata, T.: Synergistic analyses of optical and microphysical properties of agricultural crop residue burning aerosols over the Indo-Gangetic Basin (IGB), Atmos. Environ., 57, 205-218, 2012.

Mohanraj, R. and Azeez, P.: Health effects of airborne particulate matter and the Indian scenario, Curr. Sci. India, 87, 741-748, 2004

Mooley, D.: The role of western disturbances in the production of weather over India during different seasons, Indian J. Meteor. Geophys., 8, 253-260, 1957.

NAAQS: National Ambient Air Quality Standard 2009, The Gazette of India, Extraordinary, Kartika 27, 1931, Government of India, New Delhi, 2009.

Nag, S., Gupta, A., and Mukhopadhyay, U.: Size distribution of atmospheric aerosols in Kolkata, India and the assessment of pulmonary deposition of particle mass, Indoor Built Environ., 14, 381-389, 2005.

Nemery, B., Hoet, P. H., and Nemmar, A.: The Meuse Valley fog of 1930: an air pollution disaster, Lancet, 357, 704-708, 2001.

Nyanganyura, D., Makarau, A., Mathuthu, M., and Meixner, F. X.: A five-day back trajectory climatology for Rukomechi research station (northern Zimbabwe) and the impact of large-scale atmospheric flows on concentrations of airborne coarse and fine particulate mass, S. Afr. J. Sci., 104, 43-52, 2008

Pandey, J. S., Kumar, R., and Devotta, S.: Health risks of $\mathrm{NO}_{2}$, SPM and $\mathrm{SO}_{2}$ in Delhi (India), Atmos. Environ., 39, 6868-6874, 2005.

Pandithurai, G., Dipu, S., Dani, K., Tiwari, S., Bisht, D., Devara, P., and Pinker, R.: Aerosol radiative forcing during dust events over New Delhi, India, J. Geophys. Res.-Atmos., 113, D13209, doi:10.1029/2008jd009804, 2008.

Pease, P. P., Tchakerian, V. P., and Tindale, N. W.: Aerosols over the Arabian Sea: geochemistry and source areas for aeolian desert dust, J. Arid Environ., 39, 477-496, 1998.

Pisharoty, P. and Desai, B.: Western disturbances and Indian weather, Indian J. Meteorol. Geophys., 8, 333-338, 1956.

Pope III, C.: Epidemiology of fine particulate air pollution and human health: biologic mechanisms and who's at risk?, Environ. Health Persp., 108, 713-723, 2000.

Pope III, C. A. and Dockery, D. W.: Health effects of fine particulate air pollution: lines that connect, J. Air Waste Manage., 56, 709742,2006
Pope III, C. A., Thun, M. J., Namboodiri, M. M., Dockery, D. W., Evans, J. S., Speizer, F. E., and Heath Jr., C. W.: Particulate air pollution as a predictor of mortality in a prospective study of US adults, Am. J. Resp. Crit. Care, 151, 669-674, 1995.

Pöschl, U., Martin, S. T., Sinha, B., Chen, Q., Gunthe, S. S. Huffman, J. A., Borrmann, S., Farmer, D. K., Garland, R. M., Helas, G., Jimenez, J. L., King, S. M., Manzi, A., Mikhailov, E., Pauliquevis, T., Petters, M. D., Prenni, A. J., Roldin, P. Rose, D., Schneider, J., Su, H., Zorn, S. R., Artaxo, P., and Andreae, M. O.: Rainforest aerosols as biogenic nuclei of clouds and precipitation in the Amazon, Science, 329, 1513-1516, doi:10.1126/science.1191056, 2010.

Ramaswamy, C.: On the sub-tropical jet stream and its role in the development of large-scale convection, Tellus, 8, 26-60, 1956.

Rao, P. S. and Sikka, D. R.: Intraseasonal variability of the summer monsoon over the North Indian Ocean as revealed by the BOBMEX and ARMEX field programs, Pure Appl. Geophys., 162, 1481-1510, doi:10.1007/s00024-005-2680-0, 2005.

Sarkar, C., Kumar, V., and Sinha, V.: Massive emissions of carcinogenic benzenoids from paddy residue burning in North India, Curr. Sci. India, 104, 1703-1706, 2013.

Schrenk, H. H., Heimann, H., Clayton, G. D., Gafafer, W., and Wexler, H.: Air Pollution in Donora, Pa. Epidemiology of the Unusual Smog Episode of October 1948, Preliminary Report, Public Health Bulletin, no. 306, Washington, D.C., Federal Security Agency, Public Health Service, Bureau of State Services, Division of Industrial Hygiene, 173 pp., 1949.

Schwartz, J.: Air pollution and daily mortality: a review and meta analysis, Environ. Res., 64, 36-52, 1994.

Sharma, D., Singh, D., and Kaskaoutis, D.: Impact of two intense dust storms on aerosol characteristics and radiative forcing over Patiala, northwestern India, Adv. Meteorol., 2012, 956814, doi:10.1155/2012/956814, 2012.

Shy, C. M.: Epidemiologic evidence and the United States air quality standards, Am. J. Epidemiol., 110, 661-671, 1979.

Sikka, D. R.: Evaluation of monitoring and forecasting of summer monsoon over India and a review of monsoon drought of 2002, Proceedings - Indian National Science Academy Part A, 69, 479-504, 2003

Sikka, D. R. and Gadgil, S.: On the maximum cloud zone and the ITCZ over Indian, longitudes during the Southwest Monsoon, Mon. Weather Rev., 108, 1840-1853, doi:10.1175/15200493(1980)108<1840:OTMCZA>2.0.CO;2, 1980.

Singh, N., Mittal, S. K., Agarwal, R., Awasthi, A., and Gupta, P. K.: Impact of rice crop residue burning on levels of $\mathrm{SPM}, \mathrm{SO}_{2}$ and $\mathrm{NO}_{2}$ in the ambient air of Patiala (India), Int. J. Environ. An. Ch., 90, 829-843, 2010.

Sinha, V., Kumar, V., and Sarkar, C.: Chemical composition of premonsoon air in the Indo-Gangetic Plain measured using a new air quality facility and PTR-MS: high surface ozone and strong influence of biomass burning, Atmos. Chem. Phys., 14, 59215941, doi:10.5194/acp-14-5921-2014, 2014.

Stohl, A.: Trajectory statistics - a new method to establish sourcereceptor relationships of air pollutants and its application to the transport of particulate sulfate in Europe, Atmos. Environ., 30, 579-587, doi:10.1016/1352-2310(95)00314-2, 1996. 
Stohl, A.: Computation, accuracy and applications of trajectories - a review and bibliography, Atmos. Environ., 32, 947-966, doi:10.1016/S1352-2310(97)00457-3, 1998.

Venkataraman, C., Habib, G., Eiguren-Fernandez, A., Miguel, A., and Friedlander, S.: Residential biofuels in South Asia: carbonaceous aerosol emissions and climate impacts, Science, 307, 1454-1456, 2005.
Ware, J. H., Thibodeau, L. A., Speizer, F. E., Colóme, S., and Ferris Jr., B. G.: Assessment of the health effects of atmospheric sulfur oxides and particulate matter: evidence from observational studies, Environ. Health Persp., 41, 255-276, 1981. 